\title{
İletişim Temalı Turist Rehberliği Çalışmalarının Biblioshiny Programı ile Bibliyometrik Analizi
}

\section{Bibliometric Analysis of Communication-Themed Studies in The Field of Tourist Guiding with Biblioshiny Program}

\author{
Dr. Öğr. Üyesi Semih ARICI \\ Pamukkale Üniversitesi, Turizm Fakültesi, Türkiye \\ Pamukkale University, Faculty of Tourism, Turkey \\ E-Mail: sarici@pau.edu.tr \\ Prof. Dr. Elbeyi PELITT \\ Afyon Kocatepe Üniversitesi, Turizm Fakültesi, Türkiye \\ Afyon Kocatepe University, Faculty of Tourism, Turkey \\ E-Mail: elbeyipelit@aku.edu.tr
}

$\ddot{O} \mathbf{z}$

Amaç ve Önem: Bu çalışmanın amacı, 1988 - 2020 yılları arasında yayımlanmış iletişim temalı turist rehberliği çalışmalarını bibliyometrik yöntemle, çeşitli parametreler kullanılarak, analiz etmek ve turist rehberliği alan yazınına ve araştırmacılara katkı sağlamaktır.

Yöntem: Bu kapsamda Web of Science veri tabanında "tour guide"+ "communication" anahtar kelimeleriyle tarama yapılarak 2020 yılına kadar olan 256 farklı dergide yayımlanmış 318 ilişkili yayına ulaşılmıştır. Elde edilen verilerin analizinde açık kaynak kodlu RStudio Version (1.4.1717) programı ve bir R program aracı olan "biblioshiny for bibliometrix" uygulaması kullanılmıştır.

Bulgular: Araştırma sonucunda iletişim temalı turist rehberliği çalışmalarında en fazla müşteri memnuniyeti, turist rehberinin performansı, iletişim teknolojileri tabanlı rehberlik uygulamaları, sanal gerçeklik, destinasyon imajı, destinasyon pazarlaması vb. konuların çalışıldığ 1 görülmüştür. Çalışmaların en çok yayımlandığı dergiler ile en çok atıf yapılan kaynak dergiler arasında bir farklılı̆ı̆ın olduğu görülmüş ve bu farklılığın iletişim temalı turist rehberliği çalışmalarının çoğunlukla turizm turist rehberliği uzmanlık alanları dışında çalışan araştırmacılar tarafından yapılmasından kaynaklandığı tespit edilmiş̧ir.

Özgünlük/Bilimsel Katkı: İletişsim temalı turist rehberliği çalışmalarının yıllar içesinde iletişimden sosyal medya iletişimine, gerçeklikten sanal gerçekliği doğru evrildiği tespit edilmiştir. Ayrıca elde edilen veriler Lotka yasasına göre analiz edildiğinde, iletişim temalı turist rehberliği alan yazınının yetersiz ve gelişmeye muhtaç olduğu sonucuna ulaşılmış̧ır.

Anahtar Kelimeler: Turist rehberi, iletişim, turizm, bibliyometrik analiz, bibliyoshiny.

Makale Türü: Araştırma makalesi

\section{Abstract}

Purpose and Importance: The aim of this research is to analyze the communication themed articles in the field of tourist guiding and published between the years of $1988-2020$ with the method of bibliometric analysis and using different parameters and to contribute to tourist guiding literature and researchers.

Atıf için (for cited); Arıcı, S. ve Pelit, E. (2021). İletişim temalı turist rehberliği çalışmalarının biblioshiny programı ile bibliyometrik analizi, Turist Rehberliği Dergisi, 4(2), 80-105. 
Methodology: Within this scope, "tour guide" + "communication" keywords have been searched in Web of Science database and 318 articles published in 256 different journals until 2020 have been detected. For the analysis of the findings, open source RStudio Version (1.4.1717) program and "biblioshiny for bibliometrix" application which is a R program tool have been used.

Findings: As a result of the research, it has been found out that mostly customer satisfaction, performance of tourist guides, communication technologies-based guide applications, virtual reality, destination image, destination marketing etc. topics have been researched in communication-themed tourist guiding studies. It has been noticed that there is a difference between the journals in which the researches have been published most and the most-referenced journals and this difference is resulted because communication-themed tourist guiding researches are done by mostly the researchers working in fields of studies which are other than tourism - tourist guide fields.

Originality/Value: It has been found out that relevant researches evolved from communication to social media communication, from reality to virtual reality over the years. In addition, findings have been analyzed according to Lotka's law and it has been inferred from this analysis that communicationthemed tourist guiding literature is inadequate and needs to be improved.

Keywords: Tourist guide, communication, tourism, bibliometrics analysis, bibliyoshiny.

Paper Type: Research article

\section{Giriş}

21. yüzyılda bankacılık ve finans sektöründen sonra en hızlı büyüyen sektör olan turizm sektörü, ödemeler dengesine ve istihdama yaptığı katkılardan dolayı ülkelerin önem verdikleri bir sektördür. Emek yoğun yapısı ve hizmetin müşteriye doğrudan çalışanlar ile sunulması, verimlilik ve rekabet noktasında turizm sektörü çalışanlarının önemini arttırmaktadır. Turizm sektöründe konaklama hizmeti, yiyecek içecek hizmeti, yöre halkının tutumu, fiyat, ulaşım vb. etkenler gibi, rehberin bilgi seviyesi ve iletişim becerisinde iyi olma özellikleri destinasyonu ziyaret eden turistlerin memnuniyetini doğrudan ve dolaylı etkilemektedir (Çetinkaya \& Öter, 2016). Bu noktada destinasyonu tanıtmak, turizm sektöründe pazar payını arttırmak ve gelen misafirlerin tekrar tekrar destinasyonu ziyaret etmelerini sağlamak için turist rehberlerinin iletişim becerilerinin geliştirilmiş olması gerekmektedir (Şen \& Avcıkurt, 2013).

İnsanlığın varoluşu ile ortaya çıkan ve bireylerin arasındaki etkileşimi ifade eden iletişim, modern toplumların oluşmasında son derece önemli rol oynayan bir araçtır (Kumar \& Gilula, 1996). İnsanların sahip oldukları duygu ve düşünceleri diğer insanlara anlatmalarını ve onları anlamalarını sağlamanın yoludur (Üstün, 2015). Bu açıdan iletişimin iki bireyin birbirlerini fark ettiği andan itibaren başladığını söylemek mümkündür (Cüceloğlu, 2002). Benzer bir şekilde Johnson \& Johnson (1997), bireylerin aralarındaki iletişimi, en az iki kişi arasındaki mesaj ve duyguların paylaşılması ve anlamlandırılması süreci olduğunu dile getirmişlerdir. Sosyal bir varlık olarak kabul edilen insan için iletişim olmazsa olmaz bir gereklilik olarak karşımız çıkmaktadır. Çağımız; duygu, düşünce, mesaj ve bilgilerin çok çeşitli yollar izleyerek ve farklı formlarda günlük kararlarımızın etkilendiği iletişim çağıdır (Kumar \& Gilula, 1996). Bu durumda toplumun bir ferdi olabilmenin yolu iletişim yeteneğine sahip olmaktan geçmektedir. $\mathrm{Bu}$ durum iletişimi sosyalleşmenin temel aracı haline getirmektedir (Pelit \& Karaçor, 2015).

Bireylerin aralarında kurdukları ilişkiler gibi, kendileriyle kurdukları, kitleler ile kurulan ve ulusların arasında kurdukları çeşitli iletişim türleri de bulunmaktadır. Turist rehberleri hem bireysel hem de gruplara karşı sürekli bir iletişim içerisindedirler. Bu açıdan iletişim becerileri geliştirmiş ve temel iletişim kurallarına riayet ediyor olmak mecburiyetindedirler (Arat \& Bulut, 2019). 


\section{IIIII)}

Turist Rehberliği Dergisi (TURED) \& Yıl. 2021, Cilt. 4, Sayı. 2

Journal of Tour Guiding (JOTOG) \& Year. 2021, Volume. 4, Issue. 2

Turistler, rehberin performansının yüksek olduğuna inanırlarsa, ona duydukları güven artacak ve rehberlerinin sunduğu hizmetten memnun kalacaklardır (Chang, 2014). Bunun için aralarındaki iletişimin kaliteli olması gerekmektedir. İletişim becerisine sahip olmak rehberler ile turistler arasındaki etkileşimi olumlu yönde etkilediği gibi rehberlerin işlerinden aldığ doyumun ve öz yeterliliklerinin artmasını dolayısı ile mesleki verimliliklerinin yükselmesini sağlayabilmektedir.

$\mathrm{Bu}$ noktadan hareketle çalışmamızda, iletişim temalı turist rehberliği akademik çalışmalarının bibliyometrik analizini yapmak, elde edilen verilerle turizm, turist rehberliği alanlarına katkılar sunmak, iletişim temalı turist rehberliği çalışmalarının mevcut durumunu çeşitli parametrelerle analiz ederek ilgili alanda çalışan araştırmacılara günümüz ve geleceğe dair ipuçları sunarak katkı sağlamak amaçlanmıştır.

\section{Literatür Taraması}

\section{1. İletişim}

Düşünüp konuşabilmesi ile diğer canlılardan ayrılan insan, sosyal bir varlık olup toplu halde yaşama ihtiyacı hissetmekte, bunun sonucu olarak birbirleri ve doğa ile iletişime girmek durumunda kalmaktadır (Işık, 2012). Hayatın içine işlemiş, yaşamın her anında içinde bulunduğu iletişim faaliyeti ile insan, sadece nefes alıp veren biyolojik bir canlı olmaktan çıkıp toplumun bir parçası olabilmektedir. Latince beraber, grup halinde olmak, bir araya getirmek anlamına gelen communis sözcügünden ortaya çıkmış iletişim (communication) insanların bir arada yaşayabilmesinin dolayısı ile toplumlar oluşturarak medeniyete ulaşabilmelerinin temel taşıdır. Bu noktada iletişim, insanlar arasındaki paylaşımla meydana gelen bir süreç olmasının yanı sıra insanların bir araya getirilmesiyle ortaya çıkan toplumsal bir süreç olarak da ifade edilebilir (Çağlar \& Kılıç, 2008). Toplumun oluşmasında temel taşı oluşturan bir sistem olarak görülen iletişim, işleyişin düzenli olması için gereken örgütsel bir araç, toplumu oluşturan bireylerin davranışlarını anlayıp şekillendirmeye yönelik bir teknik, meydana gelen sosyal süreci anlamaya yönelik gerekli bir bilim ve toplumun birlikte ahenk içinde yaşamını sürdürmesini sağlayan bir sanattır (Tutar \& Yılmaz, 2003). Bu doğrultuda toplumdaki bireylerin arasında etkileşim sağlayan iletişim, toplumun benzer davranış, amaç ve değerlere sahip olmasını sağlayarak birlikte hareket edip, belli konularda uzlaşmalarını sağladığı söylenebilir (Arden \& Booggs 1999, Dökmen 2003). İletişim sayesinde toplumlar kendi gelenek ve kültürlerini korurken bunları yayarak büyüyebilme firsatını yakalayabilir (Üstün, 2015).

İletişim faaliyetine giren kişiler ortak bir yol bulma, ortak bir noktada buluşma, ortak bir bilgiyi paylaşma (commonness) çabasındadırlar. Kaya (1985), iletişimin önde gelen amaçlarından birinin duygu ve düşüncelerin kişilerin arasında paylaşılarak bir ortaklık yaratmak olduğunu söylemiştir. Kısaca iletişim, yüz ve vücut hareketlerini, ses, konuşma ya da yazılı sesli görsel teknolojileri kullanarak bir duygu, düşünce ya da bilgi içeren mesajların en az iki kişi arasında iletilmesi olarak tanımlanmaktadır (Cüceloğlu, 2002; Oğuzkan, 2003). Bu açıdan etkili bir iletișim becerisinin söz, ses, vücut dili, hareketli ve hareketsiz görseller ve tüm bunlarının kombinasyonları ile mesajlar gönderebilmek ve gönderilen mesajlara karşı duyarlı olup doğru şekilde cevap verebilmek olduğu söylenebilir (Egan 1994; Johnson \& Johnson, 1997). İletişim; iletişim içinde olan bireyler, iletilmeye çalışılan mesaj, bağlam, iletişim için kullanılan kanal, mesajların anlaşılmasını engelleyebilecek çevresel ya da iç gürültü ve geri bildirimi kapsayan bir süreçtir (Verdener, 1999).

Bir iletişimin etkili olabilmesi; mesajı alan kişinin, göndericinin iletmek istediği şekilde anlayabilmesi ile gerçekleşmektedir (Johnson \& Johnson, 1997). İletişim sürecinde 


\section{IIIII)}

Turist Rehberliği Dergisi (TURED) \& Yıl. 2021, Cilt. 4, Sayı. 2

Journal of Tour Guiding (JOTOG) \& Year. 2021, Volume. 4, Issue. 2

insanlar aldıkları her mesajı kendilerince anlamlandırdıklarından ve her insanın özelliklerinin kendine özgü olmasından dolayı iki kişinin aynı mesaja birebir aynı anlamı yüklemesi mümkün değildir (Üstün, 2015). Bu yüzden etkili iletişim için mesaj söz, beden dili ve mimik gibi yollarla desteklenmeli, iletişimin gerçekleştiği çevre şartları dikkate alınmalıdır. Ayrıca olaylara ve mesajlara tek açıdan bakmak iletişim kurulmasına engel olacağından, farklı açılardan olay ve mesajlara yaklaşmanın önemli olduğu unutulmamalıdır (Özer, 2000).

Kısaca etkili iletişimin temel faktörleri, iletmek istenen mesaja hâkim olmak, söz konusu mesajın iletileceği doğru zamanı ve yeri bilmek, mesaj için en doğru kanalı ve üsluba karar vermek, en yalın ve akıcı bir dille, göz temasını ve dikkati kaybetmeden karşıdakine mesajı iletebilmek olduğu söylenebilir (Yüksel, 2006).

\subsection{Turist Rehberliği ve İletişim}

Diğer insanlar ile etkileşime girmek durumunda olunan, toplumla temasın yüksek olduğu mesleklerde çalışan kişilerin iletişim becerine sahip olmasının olumlu etkileri bilinmektedir (Egan, 1994). Örgütlerin temelini oluşturan insan kaynağının, iletişim becerilerine sahip olması çalışan memnuniyetini arttırabildiği gibi iş verimliliğine de yükseltebilmektedir (Claypool, 2003). Çünkü insanların güven verici ve tatmin eden bir ilişki başlatıp onu sürdürebilmesi, iletişim becerilerinin durumu ile doğrudan ilişkilidir (Üstün, 2015). Turizm, turistlerin farklı coğrafyaların dilini kültürlerini tanımasını ve yerel halkın da turistlerin kültürlerini öğrenebilme fırsatı yaratmaktadır. Doğru bir iletişimle ülkeler arası dostluk ve dünya barışına olumlu katkılar sağlanabilecekken başarısız bir iletişim ile yanlış anlaşılmalar ve önyargılara sebebiyet verilebilmekte, destinasyona dair negatif bir imaj yaratılmasına böylelikle turizm ve diğer sektörlerde uluslararası rekabet etme şansının kaybedilmesine sebep olunmaktadır (Şen \& Avcıkurt, 2013).

Bireysel ya da toplu olarak seyahat eden turistlerin ziyaretleri boyunca seçmiş oldukları dilde destinasyonun tarih, coğrafya ve kültürü ile kendi tecrübelerini etik kurallar çerçevesinde aktarmak için kültür ve turizm bakanlığı tarafından ruhsat verilmiş kişiler turist rehberi olarak tanımlanmaktadır (Güzel \& Köroğlu, 2014; Ünüvar, 2015). Özellikle ödemeler dengesi ve istihdama yaptığı katkılardan dolayı ülkeler için son derece önemli bir konuma gelen turizm sektöründe, turist rehberleri destinasyona gelen turistler ile doğrudan temas halinde olmalarıyla sektörün önemli oyuncularından biri haline gelmişlerdir (Li et al., 2017; Duman \& Mil, 2008). Bu bağlamda turizm rehberleri sektörde birer kalite elçileri olarak kabul edilebilmektedirler (Büyükkuru \& Aslan, 2016). Broşür, fuar, sosyal medya vb. tanıtım ve reklam araçları ile destinasyona gelmesi sağlanan turistlerin, daha sonra tekrar ziyaret etmeleri ve çevresinin de destinasyonu ziyaret etme potansiyelinin sağlanması noktasında turist rehberlerinin önemi büyüktür (Batman vd., 2001). Bir destinasyonun rehberle gezilmesi, turistin o destinasyona seyahatinde fiziki, kültürel ve psikolojik olarak doyuma ulaşmasını olumlu şekilde etkilemektedir (Arat \& Bulut, 2019)

Hizmet sektörü çalışanlarının müşterileri ile yoğun etkileşim halinde oldukları için arkadaşlık derecesinde güçlü ilişkileri olabilmektedir (Tsaur et al., 2018). Genellikle insanlar aile üyeleri, sevgilileri ve arkadaşlarında rahatlık ararlar; komşu, iş arkadaşı da etkili duygusal destek kaynağ1 olabilirler (Burleson \& Holmstrom 2008). Aynı şekilde turistler, bir hizmet sektörü çalışanı olarak turist rehberlerinin performanslarından memnun kaldıklarında onlarla güçlü bir iletişim kurma eğilimindedirler (Dönbak, 2021). Mesleğini icra ederken turist rehberlerinin ev sahibi, lider, aracı, yardımcı, öğretmen, arkadaş, satış elemanı, müfettiş, büyük elçi, şovmen, danışman gibi birbirinden farklı rollere bürünmek durumunda kaldığ görülmektedir (Tosun \& Temizkan, 2004, Yen et al., 2018). Destinasyona ulaştıkları noktadan itibaren yabancı dile hâkim ve iletişim becerisine sahip rehber beklentisinde olan turistlerin 


\section{IIIII)}

Turist Rehberliği Dergisi (TURED) \& Yıl. 2021, Cilt. 4, Sayı. 2

Journal of Tour Guiding (JOTOG) \& Year. 2021, Volume. 4, Issue. 2

beklentilerini karşılayan bir turist rehberi, turistin destinasyondan memnuniyet düzeyini artıracaktır (Arat \& Bulut, 2019). Diğer taraftan rehberin sunduğu gerçek hizmet ile turistlerin beklentileri arasında ortaya çıkabilecek uyumsuzluk ve farklı sebeplerden dolayı problemli turist rehberi hizmet ve davranışlarına dair birçok şikâyet de söz konusudur (Sandaruwani \& Gnanapala, 2016). Bu bağlamda, Türkiye'de kültür ve turizm bakanlığınca ruhsatlandırılarak turist rehberi olmamış kişilerin, yetersiz, donanımsız ve bilgisiz davranışlar ile mesleğe, müşteri memnuniyetine ve destinasyon imajına zarar vermemesi adına kültür turları yapmaları yasaklanmıştır (Yetkin, 2017).

Bir destinasyonun seyahat amacıyla seçilmesinde en önemli etkenlerden biri destinasyon imajıdır. Ülkeyi, tarihini ve gelenek göreneklerini turistlere yansıtan turist rehberleri, bölgeyi ziyaret eden yabancı turistlerin zihninde destinasyona dair imajın oluşmasında önemli bir rol oynamaktadır (İpar \& Doğan, 2013). Rehberlerin iyi bir imaj bırakmak ve etkili bir iletişim becerisine sahip olmak için; kullandığı dilde yetkin olması, dakik olması ve fiziki görünümüne özen göstermesi gibi üç unsura dikkat etmesi önemlidir (Keenan, 1997). Eser \& Çakıcı (2021) iletişim, dilbilgisi, akıcı anlatım ve nezaket gibi özelliklerin yanı sıra turist rehberlerinin fiziki görünümleri de turistlerin memnuniyetlerini etkilediğini, başarılı bir iletişim için bakımlı olmaları gerekliğini dile getirmişlerdir. Çünkü dış görünüş sözsüz iletişimin en önemli faktörlerinden biridir (Peracchio \& Luna, 2006).

Uluslararası turistlerin katıldıkları seyahatlerde turist rehberi olmasını arzulamalarının temelinde, karşılaşacakları yeni kültürel deneyimi doyurucu bir şekilde deneyimleme ve yabancı bölgede yaşayabilecekleri iletişim zorluklarına karşı önlem almak ihtiyacı vardır ( $\mathrm{Yu}$ et al., 2002). Tur rehberleri liderlik rolünü üstlenerek grubun karşlaşabileceği problemleri çözmesi önde gelen sorumluluklarından biridir (Cheng et al., 2019). Bununla birlikte turist rehberlerinden bilgi konusunda donanımlı olmaları beklenmektedir (George, 2011). Özellikle kültür turlarında sahip oldukları bilgilerin misafirlere aktarması sırasında iletişim becerisinin vazgeçilmez bir unsur olarak karşımıza çıktığı görülmektedir (Yıldırım, 2009). Turistler ile turizm şirketleri, ulaştırma şirketleri, yeme içme, konaklama, eğlence noktaları ve yerel halk arasında iletişimi sağlayan bir köprü olan turist rehberleri (Arat \& Bulut, 2019) yönlendirici ve arabulucu rolleri ile yerel halk1 turistlere tanıttığı gibi turistlerinde yerel halk tarafindan kabullenilmesini sağlayabilmekte turistlerin yabancı oldukları bu destinasyonda kültürel bir deneyim yaşayabilmelerini kolaylaştırabilmektedirler (Caber et al., 2018).

Bireyler arası iletişim kişinin benlik hissini, kendine olan saygısını, özgüvenini ve kendisine verdiği değeri anlayabilmesini sağlayabilir (Giffin \& Patton, 1997). Bilen (1995) diğer insanlar ile dengeli iletişim becerisine sahip kimselerin, olayları ve durumları objektif olarak yorumlayabildikleri, duygusal olarak güvende hissedebildikleri hem kendileri hem de çevresiyle olumlu etkileşim içinde olabildiklerini belirtmiştir. Bu bağlamda sahip olduğu iletişim becerisinin turist rehberinin öz yeterliliğini ve motivasyonunu yukarı çekerek verimliliğini yükselteceğini söylemek mümkündür (Arat \& Bulut, 2019).

İletişim becerisinin doğuştan gelen bir yetenek olduğu düşünenler olsa da eğitim düzeyi arttıkça bu becerinin arttığını gösteren (Hodges et al., 1996) ve iletişim tekniklerinin öğretilebilir olduğunu gösteren çalışmalar mevcuttur (Egan, 1994; Buckman, 2001; Corey, 2001).

İlk çağlardan beri iletişim var olsa da iletişim kurmanın şekli, yöntemi ve teknikleri değişiklik göstermekte, kültürel ve teknolojik değişimlere ayak uydurmaktadır (Işsk, 2012). Bilgi iletişim teknolojilerinin gelişmesi ile ortaya çıkan uygulamalar, turizm sektörünü de etkilemiş ve akıllı turizm kavramını literatüre kazandırmıştır (Yalçınkaya vd., 2018). Bu gelişmelerin bir örneği olarak her bir birey için özel tur rotası planlayabilen kişileştirilebilen 


\section{IIIII)}

Turist Rehberliği Dergisi (TURED) \& Yıl. 2021, Cilt. 4, Sayı. 2

Journal of Tour Guiding (JOTOG) \& Year. 2021, Volume. 4, Issue. 2

elektronik tur rehberleri kullanıcılara sunulmuştur (Malaka \& Zipf, 2000; Cheverst et al., 2002; Garcia vd., 2009). Bu elektronik rehberler kullanıcının kişisel özelliği, tercihi ve destinasyondaki görülecek yerlerin anlık durumlarına (varış zamanı, trafik, hava durumu vb.) göre en uygun rotayı sunmaktadır (Vansteenwegen \& Oudheusden, 2007). Bilgi ve iletişim teknolojilerinin sunduğu bu mobil uygulamalar ve dijital bağlantılar ile destinasyonu ziyaret eden turist ile destinasyon arasında sürdürülebilir iletişim kurmaya yöneliktir (Li et al., 2017). Aynı zamanda gelişen teknolojinin getirdiği uygulamalar, turist ile destinasyon arasında bir köprü vazifesi gören turist rehberi için yeni iletişim fırsatları olabilmektedir. Turist rehberleri teknolojinin getirdiği bu yeni iletişim araçlarına ayak uydurmalı, turistler ile kurulabilecek yeni iletişim bağları yaratmaya çalışmalıdırlar.

\section{Yöntem}

$\mathrm{Bu}$ çalışmada bibliyometrik analiz yöntemi uygulanmış olup, ilk olarak Pritchard tarafından tanıtılan bibliyometrik analiz, "belirli bir araştırma alanının uzun bir süre boyunca gelişimini izlemek için yayınlanmış akademik literatürün nicel ve nitel analizi" (Pritchard, 1969) şeklinde tanımlanmaktadır. Diğer bir değişle bir bilim dalında ya da disiplinde yapılan çalışmaların profilini belirlemeyi hedefleyen bibliyometrik analiz, bilimsel bilgi üretiminin sistemli bir şekilde gelişimini göstermektedir (Ruhanen et al., 2015).

Duygu, düşünce, mesaj ve bilgilerin çok çeşitli yollar izleyerek ve farklı formlarda günlük kararlarımızı etkilediği iletişim çağında yaşadığımız düşünüldüğünde tüm sektörlerde olduğu gibi turizm sektöründe de iletişim en önemli faktör olarak karşımıza çıkmaktadır. Turizm sektöründe turistle en fazla yüz yüze hizmet veren mesleklerin başında turist rehberliği gelmekte ve bu sebeple turist rehberliği mesleği için iletişim çok daha fazla önemli hale gelmektedir. Bu noktadan hareketle iletişim temalı turist rehberliği akademik çalışmalarının bibliyometrik analizini yapmak, elde edilen verilerle turizm, turist rehberliği alanlarına katkılar sunmak, iletişim temalı turist rehberliği çalışmalarının mevcut durumunu çeşitli parametrelerle analiz ederek ilgili alanda çalışan araştırmacılara günümüz ve geleceğe dair ipuçları sunarak katkı sağlamak amaçlanmıştır.

Söz konusu amaçlara ulaşabilmek için şu sorulara cevap aranmıştır;

1) Alanda en çok yayın yapan yazarlar kimlerdir?

2) Yayın üretiminde en güçlü ülkeler hangileridir?

3) İlgili yayınların yıllara göre dağılımı nedir?

4) Yayınların tek-çok yazarlılık durumları nelerdir?

5)Yayınlarda en çok kullanılan anahtar kelimeler nelerdir?

6) Atıf yapılan kaynak yayınlarda en çok tekrar eden anahtar kelimeler nelerdir?

7) Çalışma konuları yıllar içerisinde nasıl bir trend izlemiştir?

8) İlgili alanda çalışılan konular nelerdir?

9) İlgili alan yazın ve araştırmacıların bu alana katkıları yeterli midir?

İlgili literatür tarandığında turizm rehberliği alanında bir çok bibliyometrik analiz çalışmalarının yapıldığı; bu çalışmaların bir kısmının lisans üstü tezlerine yönelik bibliyometrik çalışmalar olduğu (Özsoy \& Çokal, 2018; Örnek \& Karamustafa, 2020; Zengin \& Atasoy, 2020; Saltık, 2020; Boyraz, Kabakulak \& Mutlu, 2020), bazılarının turist rehberliği alanında yayımlanmış makalelere yönelik bibliyometrik çalışmalar olduğu (Kaygalak-Çelebi \& Kirlar-Can, 2019; Tseng et al., 2020; Boyraz \& Kabakulak, 2020), bunun yanı sira kongre 


\section{IIIII)}

Turist Rehberliği Dergisi (TURED) \& Yıl. 2021, Cilt. 4, Sayı. 2

Journal of Tour Guiding (JOTOG) \& Year. 2021, Volume. 4, Issue. 2

bildirilerine yönelik bibliyometrik çalışmaların olduğu (Şahin \& Acun, 2015) gözlenmiştir. Ancak yapılan incelemelerde ne uluslararası çalışmalarda ne de ulusal çalışmalarda iletişim temalı turist rehberliğine yönelik bir bibliyometrik çalışmaya rastlanmamıştır. Benzer bir çalışmanın yapılmamış olması ve gelecekte iletişim konusuyla ilintili turist rehberliği çalışmaları yapacak araştırmacılara önemli katkılar sunması bu çalışmanın önemini arttırmaktadir.

1988 - 2021 yılları arasında yayımlanan iletişim temalı turist rehberliği çalışmalarının bibliyografyasını derlemek için "tour guide" + "communication" kavramları tarama anahtar kelimeleri olarak kullanılmıştır. Yapılan taramada 256 farklı dergide yayımlanmış, 170 makale, 138 bildiri, 3 kitap bölümü ve 7 eleştiri yazısından oluşan 318 ilişkili yayına erişilmiştir. Elde edilen bu veri setleri metin formatına dönüştürülmüş ve RStudio Version (1.4.1717) programında çalışan bir R program aracı olan "biblioshiny for bibliometrix" uygulamasına aktarılmıştır. Napoli Federico Üniversitesi'nden Massimo Aria tarafindan geliştirilen "biblioshiny for bibliometrix" bir java yazılımıdır. Bu yazılım bibliometrix paketinin işlevselliği ile Shiny paket ortamını kullanan web uygulamalarının kullanım kolaylığını birleştirmiş̧ bir bibliyometrik analiz uygulamasıdır (Massimo \& Corrado, 2021).

Elde edilen veriler, Biblioshiny for bibliometrix programı aracılığıla, yazarlara göre yayın sayısı, yazarların ülkeleri, dergilerin aldığı atıf sayısı, kaynakların aldığı atıf sayısı, dergilere göre yayın sayısı, yayınlarda kullanılan anahtar kelime bulutu, atıf yapılan kaynak yayınlarda kullanılan anahtar kelime bulutu, anahtar kelimelere dayalı eşdizilimlilik analizi gibi değişkenler dikkate alınarak analiz edilmiştir. Ayrıca tematik haritalama ve yıllara göre trend topik analizlerinin yapılmasının yanı sıra iletişim temalı turist rehberliği alanına yönelik çalışan araştırmacıların üretkenliği ve dolayısıyla ilgili alana yönelik çalışmaların yeterliliği "Lokta yasası" kullanılarak ortaya konmuştur. Lotka yasası; bir alana yönelik tek yayınla katkı yapan araştırmacıların tüm yayınlara oranının \%60, 2 yayınla katkı yapan araştırmacıların tek yayınla katkı yapanlara oranının 1/4, 3 yayınla katkı yapanların oranının 1/9 şeklinde olması gerektiğini öngörmektedir (Lotka, 1926).

\section{Bulgular}

Turist rehberliği alanında iletişim temalı olarak yayınlanmış WoS'ta (Web of Science) taranan bilimsel yayınlara ilişkin temel bilgiler Tablo 1'de gösterilmiştir. Buna göre; 1988 2021 yılları arasında toplam 318 çalışmanın kaleme alındığı görülmektedir. Bu yayınların 165 tanesinin makale, 3 tanesinin kitap bölümü, 5 tanesinin erken erişime açılmış makale, 7 tanesinin eleştiri yazısı ve 138 tanesinin bildiri olduğu tespit edilmiştir.

Tablo 1'de yer alan bilimsel yayınlara ilişkin diğer parametreler incelendiğinde; yıllık ortalama yayın sayısının 7,33 ve yayın başına ortalama alıntı sayısının 10,37 oluğu görülmektedir. Ayrıca söz konusu bilimsel yayınların toplam 862 araştırmacı tarafından kaleme alındığı tespit edilmiştir. Bu yazarlardan 60 tanesi tek yazarlı olarak çalışmalarını yayımlarken, 802 tanesi çalışmalarını çok yazarlı olarak yayımlamıştır. 
Turist Rehberliği Dergisi (TURED) \& Yıl. 2021, Cilt. 4, Sayı. 2

Journal of Tour Guiding (JOTOG) \& Year. 2021, Volume. 4, Issue. 2

Tablo 1

1988 - 2021 Arası Yayınlara İlişkin Temel Bilgiler

\begin{tabular}{lc}
\hline Açıklama & Sonuçlar \\
\hline VERİ HAKKINDA ANA BİLGÍLER & $1988: 2021$ \\
\hline Zaman Aralı̆̆ı & 256 \\
Kaynaklar (Dergiler, Kitaplar vb) & 318 \\
Belgeler & 7,33 \\
Yıllık Ortalama Yayın Sayısı & 10,37 \\
Yayın Başına Ortalama Alıntı Sayısı & 1,256 \\
Bir Yayının Yı1 Başı̈na Ortalama Alıntı Sayısı & \\
\hline YAYIN/BELGE TÜRÜ & 165 \\
\hline Makale & 3 \\
Kitap Bölümü & 5 \\
Erken Erişime Açık Makale & 138 \\
Bildiri & 7 \\
Eleştiri Yazısı & 862 \\
\hline ARASSTIRMACILAR & 60 \\
\hline Toplam Araştırmacı Sayısı & 802 \\
Tek Yazarlı Yayın Yazarları & \\
Çok Yazarlı Yayın Yazarları & \\
\hline
\end{tabular}

Bilimsel çalışmaların 1988 - 2021 yılları arasında yıllara göre yayımlanma oranları Şekil 1'de gösterilmektedir. Buna göre; turist rehberliği ve iletişim temalı yayınların yayımlanma oranının 2010 yılı itibariyle hızlı bir artı̧̧ gösterdiği ve toplam yayın sayısının yarısından fazlasının son beş yılda yayımlandığı gözlenmektedir. Ayrıca yıllara göre artış oranı ise $\% 11,09$ olduğu tespit edilmiştir.

\section{Sekil 1}

Yayınların Yıllara Göre Dă̆ılımı

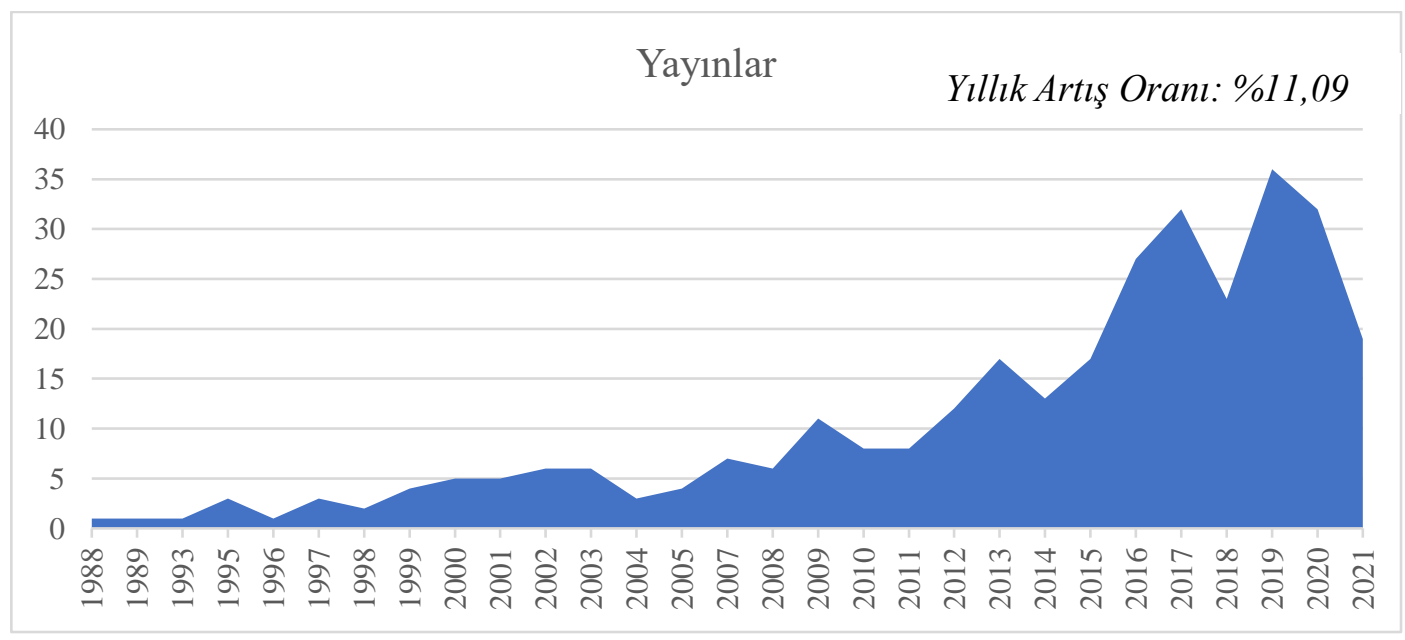

Anahtar kelimeler, yazarların adları ve çalışmaların yayımlandığı dergiler arasındaki ilişki üç alan grafiği üzerinde Şekil 2'de gösterilmiştir. Buna göre; "Turizm Rehberliği" alanında "iletişim" temalı olarak yapılan çalışmaların en çok yayımlandığı dergiler, bu dergilere en çok katkı sağlayan yazarlar ve söz konusu yazarların en çok kullandığı anahtar kelime/temalar gösterilmekte ve değişkenler arasındaki ilişki gri renkli bağlantı çizgileriyle 


\section{IIIII)}

Turist Rehberliği Dergisi (TURED) \& Y11. 2021, Cilt. 4, Sayı. 2

Journal of Tour Guiding (JOTOG) \& Year. 2021, Volume. 4, Issue. 2

görselleştirilmektedir. Grafikte yer alan dikdörtgenlerin boyutu; bu öğelerin her biriyle ilişkili çok sayıda yayın olduğunu gösterir.

Üç alan grafiğginin solunda yazarların adını gösteren ilk değişken yer almakta ve bu alanda 10 farklı yazarın ismi listelenmektedir. Ayrıca grafiğin ortasında yer alan anahtar kelime/temalar ile olan ilişkisi de görselleştirilmektedir. Buna göre en fazla yayın yapan araştırmacıların Gavalas D., Konstantopoulos C. ve Pantziou G. olduğu görülmektedir. Söz konusu yazarların turist rehberliği ile ilişkili olarak çalışma konuları/temalarının "Yön bulma problemi" ve "mobil uygulamalar" olduğu göze çarpmaktadır. Peşi sıra en çok yayın yapan araştırmacıların ise Rashid Ra., ve Mamat R. olduğu ve çalışma anahtar kelimelerinin "turist rehberliği" ve "kültürlerarası iletişim" olduğu görülmektedir.

\section{SSekil 2}

Anahtar Kelimeler, Yazarlar ve Dergiler Arasındaki İlişkinin Üç Alan Grafiği ile (Sankey Diagramı) Gösterimi

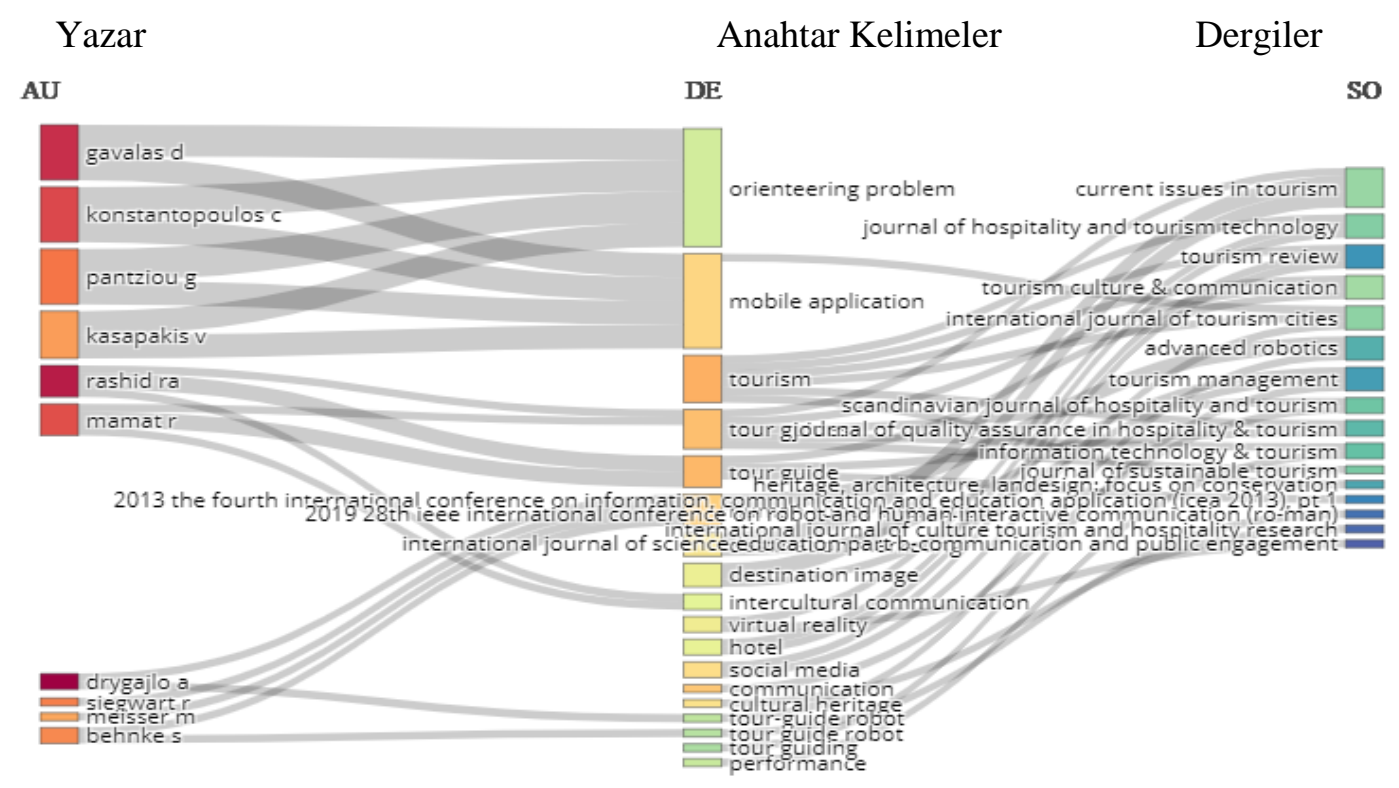

Şekil 2'de yer alan üç alan grafiğinin orta bölümünde en sık kullanılan 20 anahtar kelime/temalar yer almakta olup, en sık kullanılan anahtar kelimelerin; yön bulma problemi, mobil uygulamalar, turizm ve turist rehberliği olduğu, bunun peşi sıra; insan - robot etkileşimi, destinasyon imajı, destinasyon pazarlaması, kültürlerarası iletişim, sanal gerçeklik, sosyal medya, iletişim, robot turist rehberliği ve performans olduğu görülmektedir.

Son olarak üç alan grafiğinin sağ bölümünde iletişim konusuyla ilişkili turist rehberliği çalışmalarının en çok yayımlandığı 16 dergi listelenmektedir. Buna göre konuyla ilgili en çok yayım yapılan derginin "Current Issues in Tourism" olduğu göze çarparken, peşi sıra "Journal of Hospitality and Tourism Technology", "Tourism Review", "Tourism Culture and Communication", "International Journal of Tourism Cities", "Advanced Robotics" ve "Tourism Management" olduğu göze çarpmaktadır. En çok yayım yapılan dergilerle anahtar kelime/temalar arasındaki ilişki değerlendirildiğinde, en çok yayım yapılan dergi "Current Issues in Tourism"de yayımlanan çalışmalarda sık kullanılan temaların; turist rehberi, destinasyon pazarlaması ve destinasyon imajı olduğu görülmektedir. Peşi sıra gelen dergiler 


\section{IIIII)}

Turist Rehberliği Dergisi (TURED) \& Yıl. 2021, Cilt. 4, Sayı. 2

Journal of Tour Guiding (JOTOG) \& Year. 2021, Volume. 4, Issue. 2

ile anahtar kelimeler arasındaki ilişkide aynı anahtar kelimelerin tekrar göze çarpmasıyla birlikte, sosyal medya, sanal gerçeklik, kültürler arası iletişim, iletişim, kültürel miras gibi anahtar kelimelerin sıklıkla kullanıldığı görülmektedir. Ayrıca "mobil uygulamalar" ve "Yön bulma problemi" temaları ile yapılan çalışmaların sadece "International Journal of Tourism Cities" isimli dergide yayınlandığı görülmektedir.

Lotka yasasına göre bilimsel üretkenlik dağılımı Şekil 3’te gösterilmektedir. Şekil 3 incelendiğinde, iletişim temalı turist rehberliği çalışmaları yapan araştırmacıların \%92,1'inin sadece bir yayın yaptığı, iki yayın yapan yazarların oranının ise $\% 5$ olduğu ve geri kalan yaklaşık \%3'lük kısımda ise araştırmacıların alana ilişkin 3 ile 5 arasında çalışma yayınlandığı görülmektedir. Bilindiği üzere Lotka yasası, bir alana yönelik tek yayınla katk1 yapan araştırmacıların tüm yayınlara oranının \%60, 2 yayınla katkı yapan araştırmacıların tek yayınla katkı yapanlara oranının $1 / 4,3$ yayınla katkı yapanların oranının $1 / 9$ şeklinde olması gerektiğini öngörmektedir (Lotka, 1926). Bu bağlamda iletişim temalı turist rehberliği çalışmaları Lotka yasasına göre değerlendirildiğinde ilgili alan yazının yetersiz ve geliştirilmesi gerektiği sonucuna varılmıştır.

\section{Şekil 3}

Lotka Yasasına Göre Bilimsel Üretkenlik Dağılımı

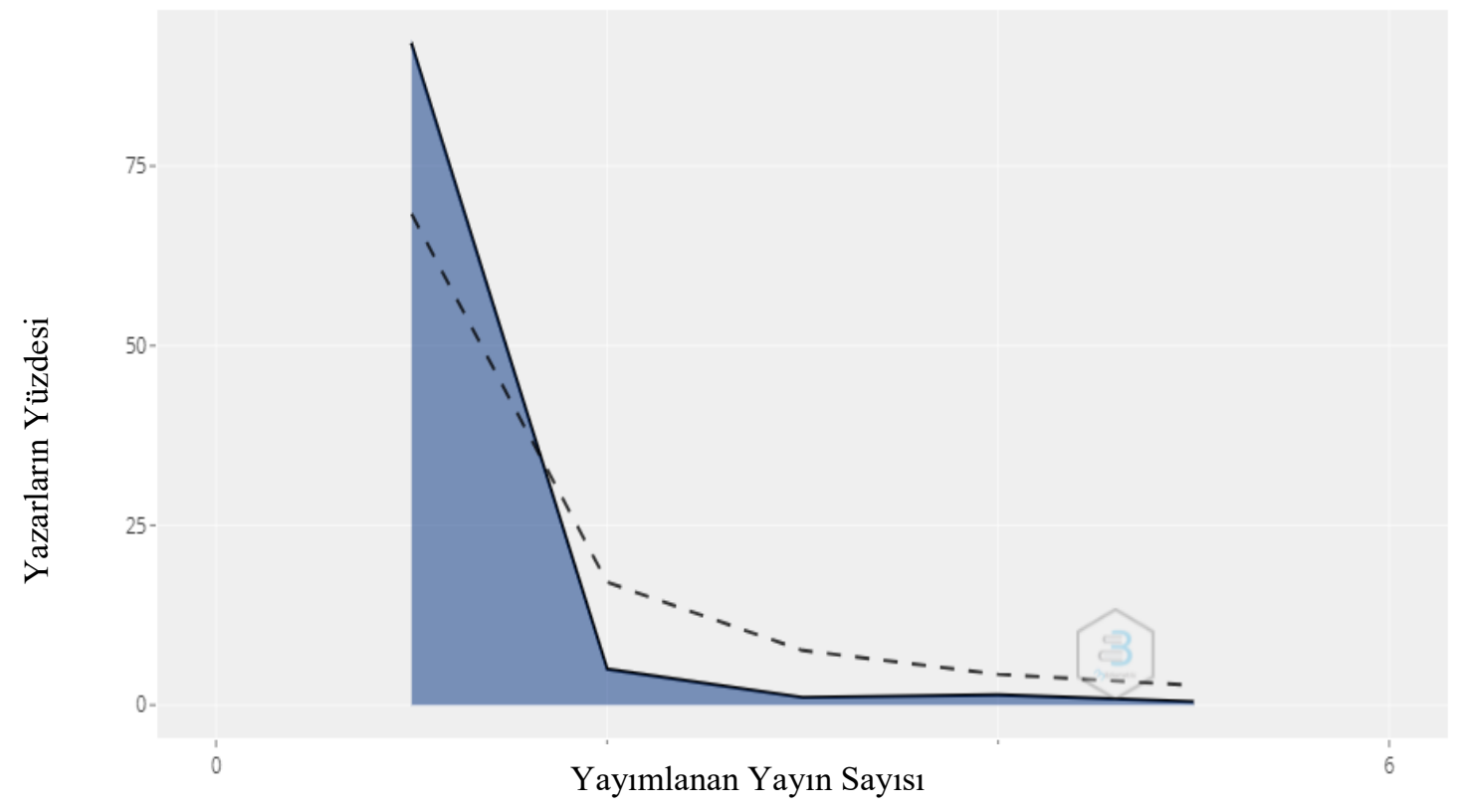

Şekil 4'te turist rehberliği çalışmaları içerisinde iletişim temasıyla alaka düzeyine dayalı olarak her bir dergi tarafından yayınlanan çalışmaların sayısı gösterilmektedir. Şekil 4 'te konuyla ilişkili en fazla yayım yapan dergilerin isimlerinin bulunduğu bir liste ve yanlarında farklı renklerle gösterilen daireler ve içlerinde yayın sayıları gösterilmektedir. Buna göre; yayın sayısı aralığının 0 ile 8 arasında olduğu ve en fazla temayla ilişkili yayın yapılan derginin "sekiz" yayın sayısıyla "Tourism Culture and Communication" isimli dergi olduğu görülmektedir. Söz konusu dergiye en yakın sayıda yayım yapan 5 adet dergi olduğu ve bu dergilerin de beşer yayın yaptı̆̆g görülmektedir. 


\section{IIIII! $\odot$}

Turist Rehberliği Dergisi (TURED) \& Y11. 2021, Cilt. 4, Sayı. 2

Journal of Tour Guiding (JOTOG) \& Year. 2021, Volume. 4, Issue. 2

\section{Şekil 4}

En Illgili Kaynaklar

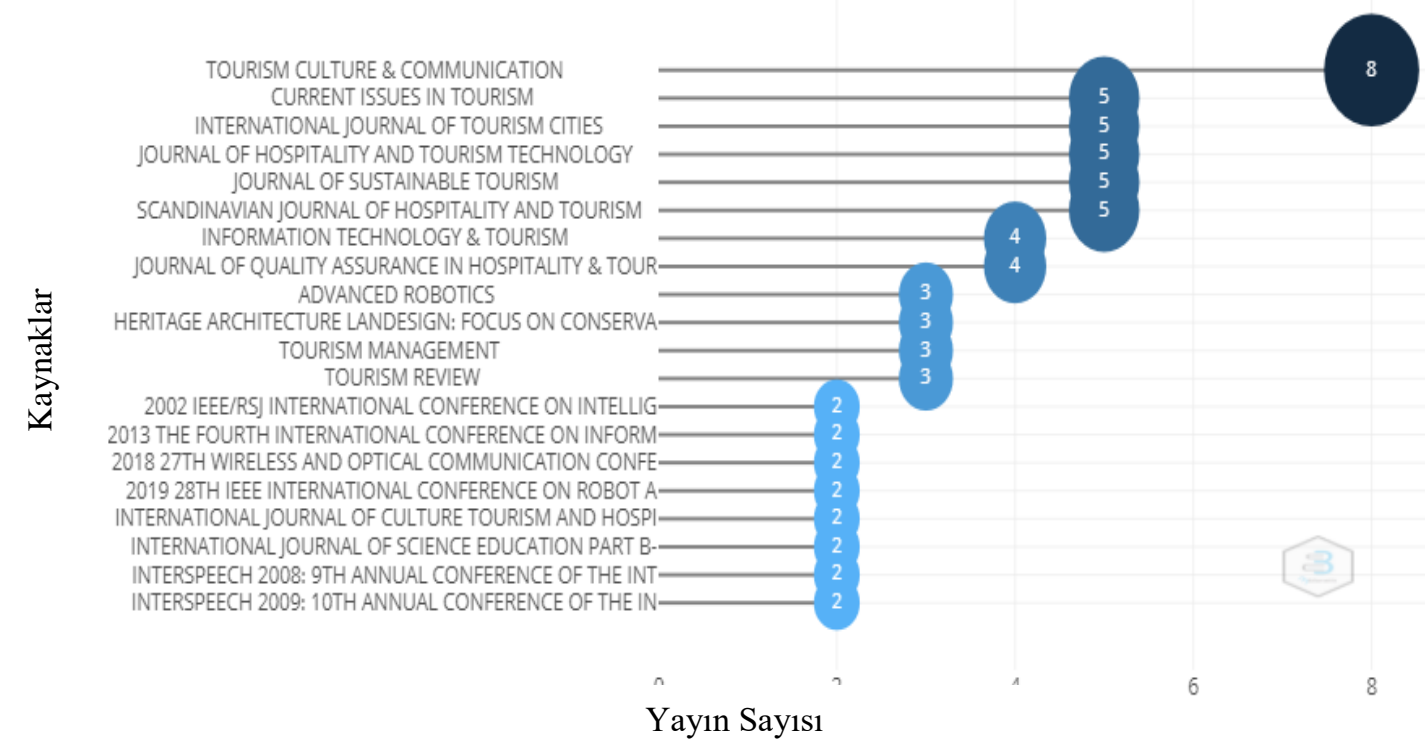

İletişim temalı turist rehberliği çalışmalarında başvurulan kaynak çalışmaların en çok yayınlandığı dergiler ve atıf sayıları Şekil 5'te gösterilmektedir. Buna göre; ilgili çalışmaların alan yazın taramasında en çok başvurulan kaynak derginin 330 atıfla "Tourism Management" isimli dergi olduğu, 281 atıfla yakından takip eden derginin ise "Annals of Tourism Research" isimli dergi olduğu göze çarpmaktadır. Şekil 4'te yer alan veriler ile Şekil 5 karşılaştırıldığında; iletişim temalı turist rehberliği çalışmalarının en çok yayımlandığı dergiler ile kaynak yayınların bulunduğu dergilerin sıralama açısından farklılaştığı görülmektedir.

\section{Sekil 5}

Kaynakçalara Göre En Çok Atıf Alan Çalışmaların Yayımlandı̆̆ı Kaynaklar

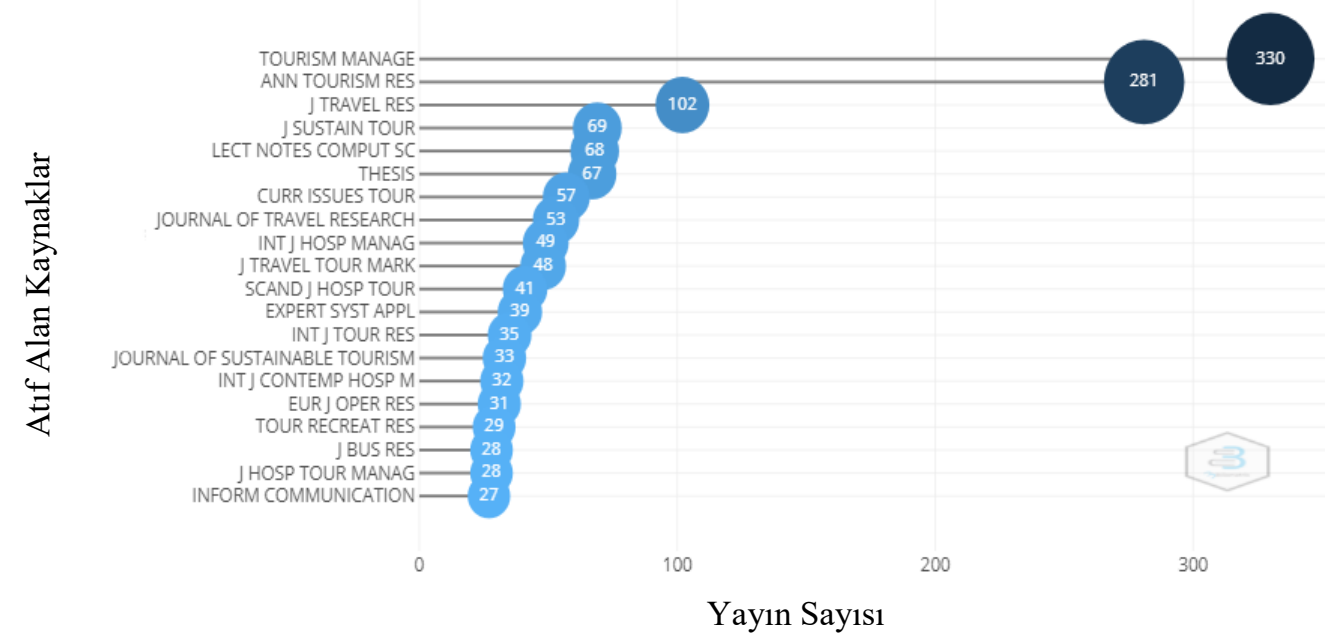


Şekil 6'da iletişim temalı turist rehberliği çalışmalarına yönelik en ilgili 20 yazar listelenmektedir. Buna göre 5'er yayınla Drygajlo A., Hori C., Mısu T. ve Rashid Ra konuya ilişkin en fazla yayın yapan araştırmacılar olarak karşımıza çıkmaktadır. Ayrıca 12 araştırmacının 4'er ve 4 araştırmacının ise 3'er yayımlanmış çalışmasıyla ilk 20 içerisine girdiği görülmektedir.

\section{Şekil 6}

Konuya Göre En İlgili Yazarlar

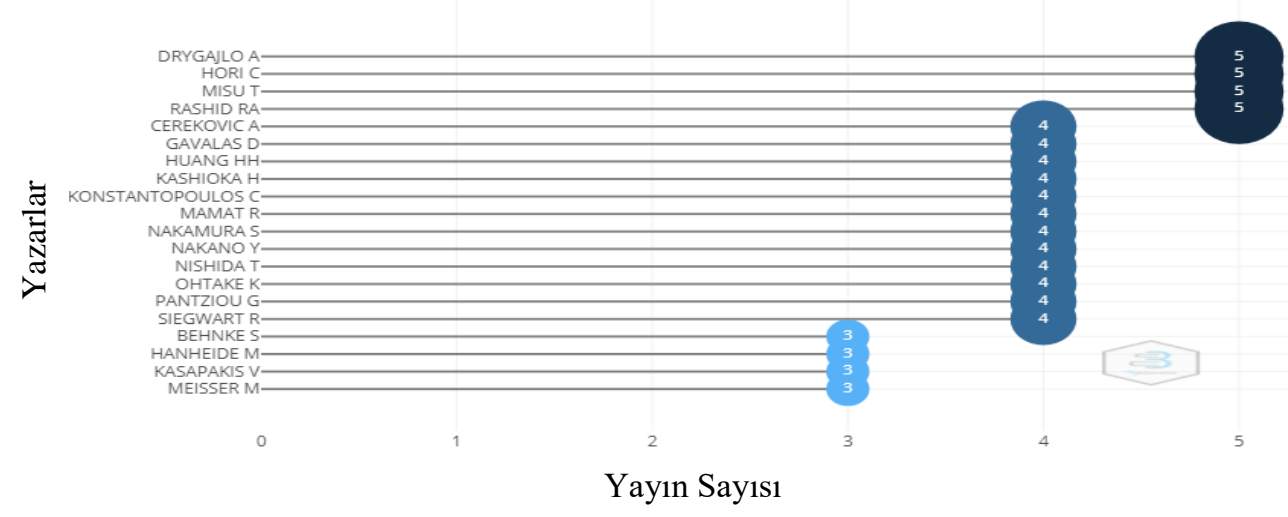

Şekil 7'de iletişim temalı turist rehberliği çalışmalarının sorumlu (iletişim) yazarlarının ülkelerine göre yayın dağılımları gösterilmektedir. En çok yayın yapan 20 ülkenin listelendiği Şekil 7'de ülkelerin yayın sayılarının 0 ile 50 arasında olduğu görülmektedir. 50 yayımlanmış çalışmayla birinci sırada listelenen ABD'yi en yakın takip eden ülkenin 40'ın üzerinde yayın sayısıyla Çin olduğu göze çarpmaktadır. Ayrıca grafikte yayın sayılarını ifade eden mumların iki farklı renkte gösterildiği görülmektedir. Bu renklerden "kırmızı" birden fazla ülkeden yazarı olan yayınları, "Turkuaz" renk ise tek ülkeden yazara/yazarlara sahip olan yayınları ifade etmektedir. Buna göre; birden fazla ülkenin iş birliği içerisinde hazırlamış olduğu çalışmaların en fazla olduğu ülkelerin yine $A B D$ ve Çin olduğu gösterilmektir.

\section{Sekil 7}

Sorumlu Yazar Ülkelerine Göre Yayın Dă̆ılımları

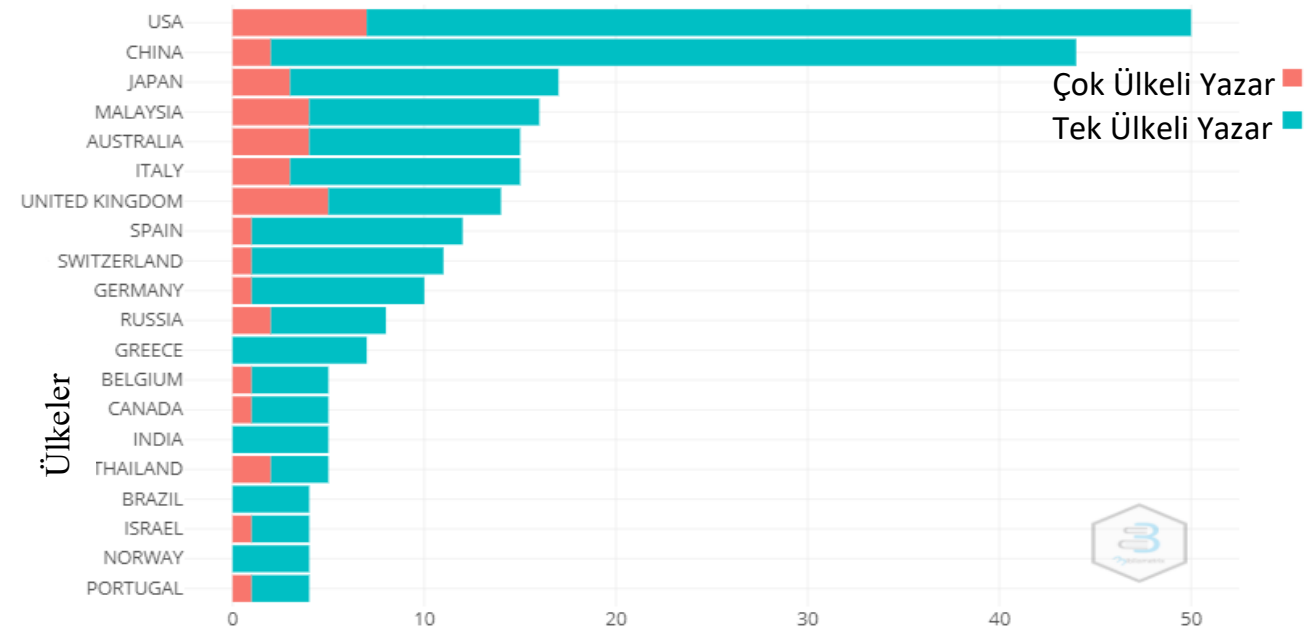


Turist Rehberliği Dergisi (TURED) \& Yıl. 2021, Cilt. 4, Sayı. 2

Journal of Tour Guiding (JOTOG) \& Year. 2021, Volume. 4, Issue. 2

WoS'ta taranan iletișim temalı turist rehberliği çalıșmalarının ve bu çalıșmalarda atıf yapılan ve kaynakçalarında yer alan ilişkili yayınların anahtar kelimeleri Tablo 2'de karşılaştırılmıştır. Sol sütunda WoS'ta taranan dergilerde yayımlanmış 318 çalışmada kullanılan 451 farklı anahtar kelimeden en sık kullanılan 20 anahtar kelime gösterilmiştir. Sağ sütunda ise araştırmaya konu olan 318 çalışmanın alan yazın taramasında kullanılmış, atıf yapılan kaynak yayınlara ilişkin anahtar kelimeler ve kullanım sıklıkları gösterilmiştir. Kaynak yayınlarda toplamda 1110 farklı anahtar kelimenin kullanıldığ tespit edilmiş olup Tablo 2'de bunların içinden en sık kullanılan 20 anahtar kelime gösterilmiştir. Tablo incelendiğinde çalışmaya konu olan 318 yayında en sık kullanılan üç kelimenin $26 \mathrm{kez}$ kullanılan "turizm", $24 \mathrm{kez}$ kullanılan turist rehberi (turist rehberleri kelimesiyle birleştirilmiştir) ve 8 kez kullanılan "iletişim”" kelimeleri olduğu göze çarpmaktadır.

Ayrıca sağ sütunda yer alan, iletişim temalı turist rehberliği çalışmalarında başvurulan kaynak yayınlarda kullanılan anahtar kelimelerin sıklıkları incelendiğinde; en sık kullanılan üç kelimenin; 17 kez kullanılan "Memnuniyet", $11 \mathrm{kez}$ kullanılan "İletişim" ve $11 \mathrm{kez}$ kullanılan "Performans" kelimeleri olduğu görülmektedir.

Tablo 2

Yayınların Anahtar Kelimelerinde ve Kaynak Yayınların Anahtar Kelimelerinde En Sik Kelimelerin Karşılaşıtırılması

\begin{tabular}{|c|c|c|c|}
\hline \multirow{2}{*}{$\begin{array}{l}\text { Yayınların Anahtar Kelimeleri } \\
(451 \text { Iccinde Ilk 20) } \\
\text { Kelimeler }\end{array}$} & \multicolumn{3}{|c|}{$\begin{array}{l}\text { Kaynak Yayınların Anahtar Kelimeleri } \\
\text { (1110 içinde İk 20) }\end{array}$} \\
\hline & Sıklık & Kelimeler & Sıklık \\
\hline Turizm & 26 & Memnuniyet & 17 \\
\hline Turist Rehberi & 14 & İletişim & 11 \\
\hline Turist Rehberleri & 10 & Performans & 11 \\
\hline İletişim & 8 & Etki & 10 \\
\hline İnsan - Robot Etkileşimi & 6 & Yönetim & 9 \\
\hline Mobil Uygulamalar & 6 & Turizm & 9 \\
\hline Sosyal Medya & 6 & Konuk Severlik & 8 \\
\hline Kültürel Miras & 5 & Davranış & 7 \\
\hline Destinasyon Pazarlaması & 5 & İnternet & 7 \\
\hline İnsan Merkezli Bilgi İşlem & 5 & Model & 7 \\
\hline Sanal Gerçeklik & 5 & Alg1lar & 7 \\
\hline Destinasyon İmajı & 4 & Deneyim & 6 \\
\hline Otel & 4 & Bilgi & 6 \\
\hline Kültürlerarası İletişim & 4 & Sosyal Medya & 6 \\
\hline Müze & 4 & Destinasyon İmajı & 5 \\
\hline Yön Bulma Sorunu & 4 & Miras & 5 \\
\hline Performans & 4 & Niyet & 5 \\
\hline Tur- Rehberi Robotu & 4 & Dil & 5 \\
\hline Tur Rehberi Robotu & 4 & Sistem & 5 \\
\hline Tur Rehberliği & 4 & Belirleyici Faktörler & 4 \\
\hline
\end{tabular}

Tablo 2 genel olarak değerlendirildiğinde, yayınlanan çalışmalara ilişkin en sık kullanılan anahtar kelimelerin turizm, turist rehberi ve iletişim olması; bu çalışmada iletişim temalı turist rehberliğine yönelik çalıșmaların bibliyometrik analizinin yapılması temel amacına uygun verilere ulaşıldığını gösterir niteliktedir. Ayrıca kaynaklara ilişkin anahtar kelimelerde en sık kullanılan kelimelerin memnuniyet, performans, iletişim ve etki kelimeleri olarak karşımıza çıkması; iletişim temalı turist rehberliği çalışmalarında iletişimin müşteri memnuniyeti üzerindeki etkisinin ve turist rehberlerinin ve tur programlarının performansları üzerinki öneminin yaygın olarak araştırıldığını ortaya koymaktadır. 


\section{IIIII)}

Turist Rehberliği Dergisi (TURED) \& Yıl. 2021, Cilt. 4, Sayı. 2

Journal of Tour Guiding (JOTOG) \& Year. 2021, Volume. 4, Issue. 2

İletişim temalı turist rehberliği araştırmalarında yıllara göre trend topik araştırma konularının neler olduğu Şekil 8'de ortaya konmuştur. Şekil 8 incelendiğinde trend topik konularının tespitinde 2012 -2020 yılları arasında yayınlanan çalışmaların dikkate alındığı ve toplam 11 trend topik araştırma konusun ortaya konduğu görülmektedir. Ayrıca grafik üzerinde gösterilen daireler ilgili konu üzerindeki yayın sayısını ifade etmekte olup, yayın sayısı daha fazla olan konular daha büyük daire ile görselleştirilmektedir.

\section{Sekil 8}

İlgili Yayınların Anahtar Kelimelerine ve Yıllara Göre Trend Topikler

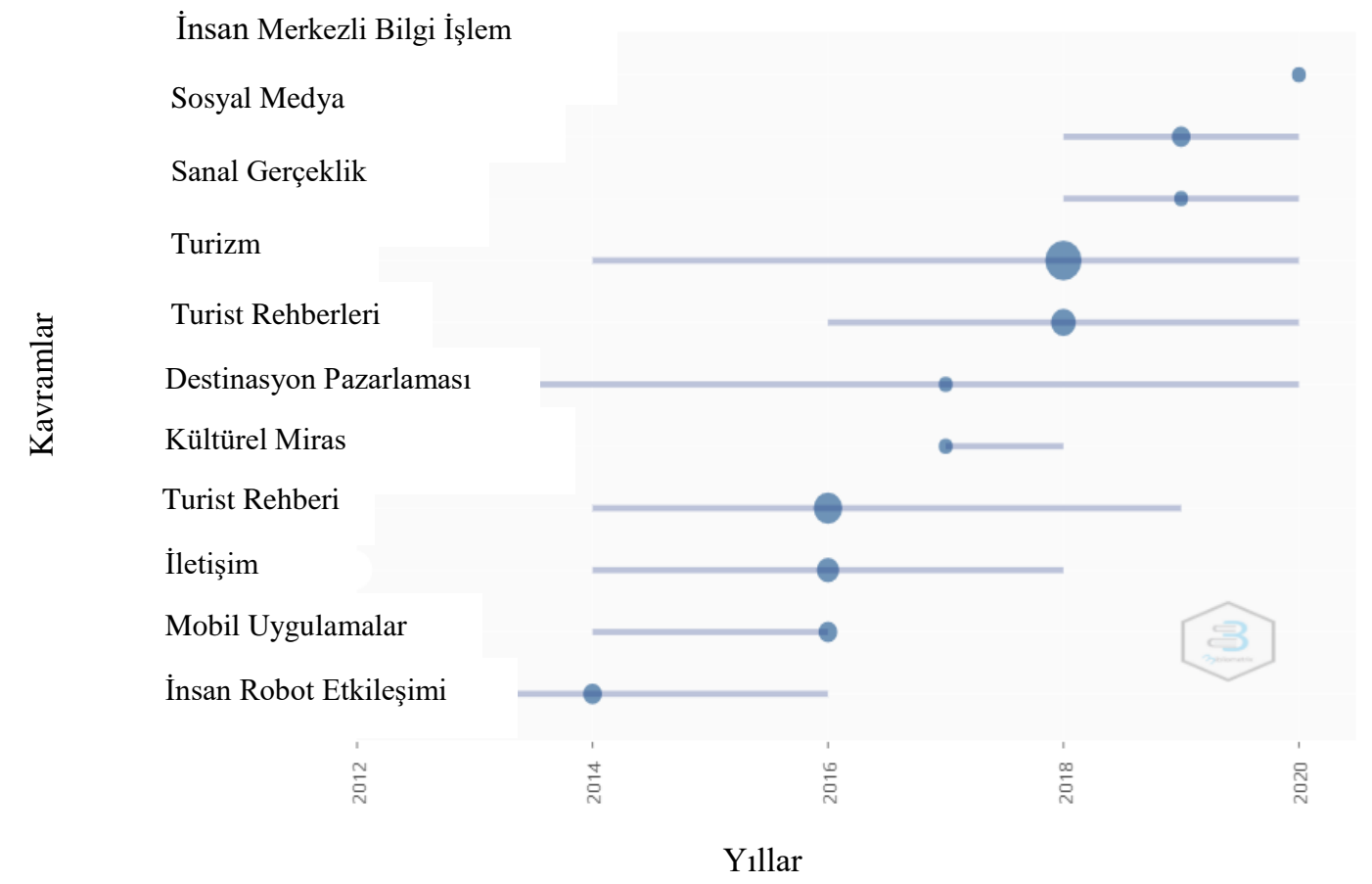

2016 y1lında mobil uygulamalar tabanlı iletişim temalı turist rehberliği çalışmaları yapılırken, 2017-2018 yıllarında turist rehberliği çalışmalarında; iletişimin destinasyon pazarlamas1 ve destinasyon imajı üzerindeki etkisinin ve kültürel mirasın korunması ile ilişkisinin araştırıldığ görülmektedir. 2019 yılında yapılan ilgili çalışmalara bakıldığında ise iletişimden sosyal medya iletişimine, gerçeklikten sanal gerçekliğe doğru bir evrilmenin söz konusu olduğu görülmektedir. Son olarak ise 2020 yılında yapılan çalışmalarda yeni trendin ise "insan merkezli bilgi işlem" konusu olduğu göze çarpmaktadır. Bu bağlamda iletişim temalı turist rehberliği çalışmalarının yıllar içerisinde teknolojinin gelişmesine ve bu gelişmenin sunduğu avantajlara dayalı olarak dönüşüm geçirdiği söylenebilir.

İletişim temalı turist rehberliği çalışmalarının anahtar kelimelerine, başlıklarına ve özetlerine ilişkin kelime bulutları ile kaynak yayınların anahtar kelimelerine ilişkin kelime bulutu Şekil 9'da gösterilmektedir.

Dört farklı değişkene ilişkin kelime bulutların görselleştirildiği şekil 9'da ilgili değişkenlerde en sık kullanılan kelime en büyük puntoyla gösterilirken en az tekrar eden kelime ise en küçük puntoyla gösterilmektedir. Ayrıca kelime bulutlarında ilgili değişken içerisinde en sik tekrar eden 50 kelimeye yer verilmektedir. 


\section{IIIII)}

Turist Rehberliği Dergisi (TURED) \& Y11. 2021, Cilt. 4, Sayı. 2

Journal of Tour Guiding (JOTOG) \& Year. 2021, Volume. 4, Issue. 2

\section{Şekil 9}

Anahtar Kelimelere, Kaynak Yayınların Anahtar Kelimelerine, Çalışmaların Başlıklarında Yer Alan Kelimelere ve Özetlere ilişkin Kelime Bulutları

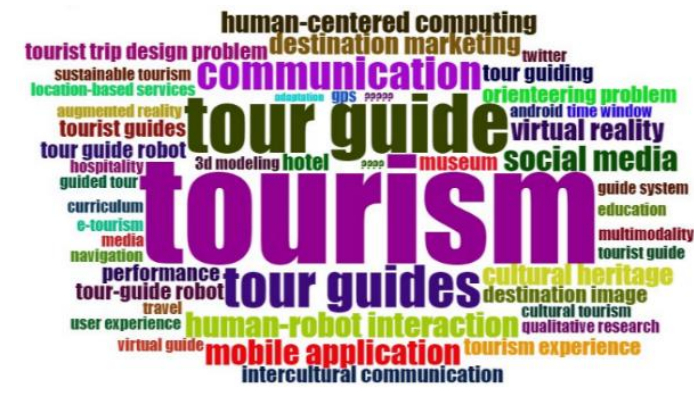

1- Anahtar Kelime Bulutu

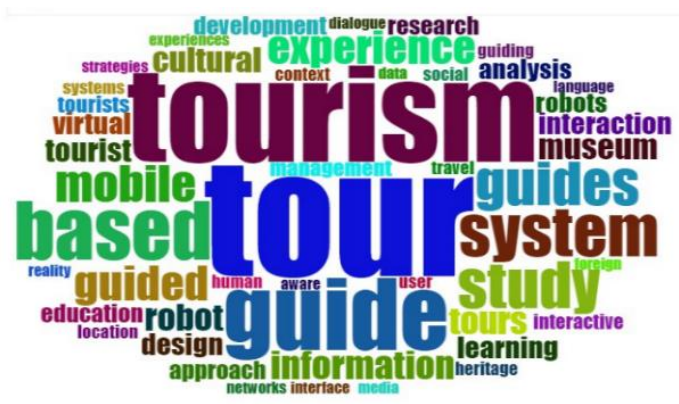

3- Başlıklara İlişkin Kelime Bulutu

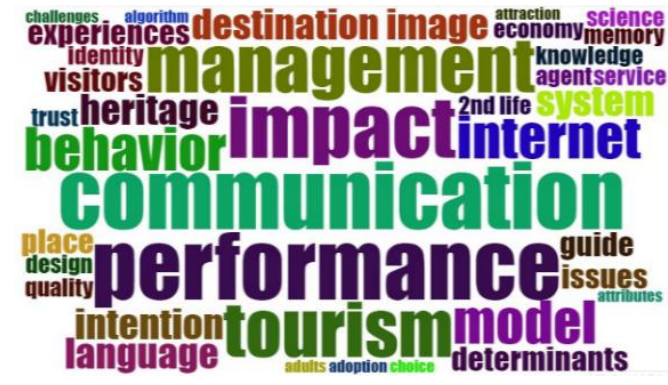

2- Kaynak Yayınlara İlişkin Kelime

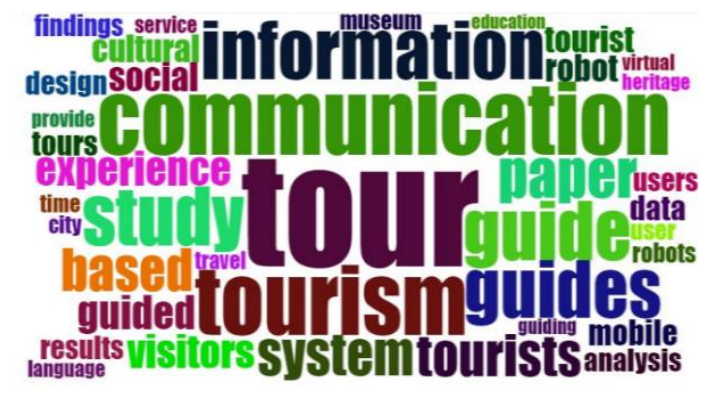

4- Özetlere İlişkin Kelime

İletişim temalı turist rehberliği çalışmalarında en sık tekrar eden anahtar kelimelerin görselleştirildiği birinci değişkende turizm en çok tekrar eden kelime olarak karşımıza çıkarken sırasıyla turist rehberi, iletişim, insan-robot etkileşimi, mobil uygulamalar, destinasyon pazarlaması ve kültürler arası iletişim kavramları en çok tekrar eden anahtar kelimeler olarak karşımıza çıkmaktadır. Kaynak yayınlarda en çok kullanılan anahtar kelimelerin görselleştirildiği ikinci kelime bulutunda ise, en çok tekrar eden anahtar kelimenin iletişim kavramı olduğu görülmektedir. İletişim kavramını takiben performans, etki, turizm, davranış, turist rehberi, tur yönetimi, niyet, bilgi, deneyim gibi kavramların en çok tekrar eden diğer kavramlar olduğu görülmektedir.

İletişim temalı turist rehberliği çalışmalarının başlıklarına ilişkin kelime bulutu üçüncü görselde verilmiş olup, başlıklarda en çok kullanılan kelimelerle anahtar kelimelerde en sık kullanılan kelimelerin paralellik gösterdiği gözlenmektedir. Son olarak araştırmaların özet kısımlarında en çok tekrar eden kelimelerin görselleştirildiği dördüncü kelime bulutunda ise en fazla tekrar eden kelimelerin hem anahtar kelime ve başlıklarda hem de atıf yapılan kaynak yayınların anahtar kelimelerinde en çok tekrar eden kelimeleri kapsayıcı nitelikte olduğu göze çarpmaktadır.

İletişim temalı turist rehberliği çalışmalarının anahtar kelimelerine ve söz konusu yayınlarda atıf yapılan kaynak yayınların anahtar kelimelerine ilişkin eşdizimlilik ağları şekil 10 ’da gösterilmiş̧ir. Söz konusu görsellerde anahtar kelimelerin bir birlerine yakınlığına göre kümelendiği görülmekte olup daire şekilleri ise ilgili anahtar kelimenin kullanıldığı yayın 


\section{IIIII)}

Turist Rehberliği Dergisi (TURED) \& Y11. 2021, Cilt. 4, Sayı. 2

Journal of Tour Guiding (JOTOG) \& Year. 2021, Volume. 4, Issue. 2

sayısının miktarını temsil etmektedir. Öyle ki ilgili anahtar kelimenin kullanıldığı yayın sayısı arttıkça daire büyümektedir.

\section{Şekil 10}

Çalışmaların Anahtar Kelimelerine ve Çalışmalarda Kullanılan Kaynak Yayınların Anahtar Kelimelerine Dayalı Eşdizimlilik A $\breve{g l}$

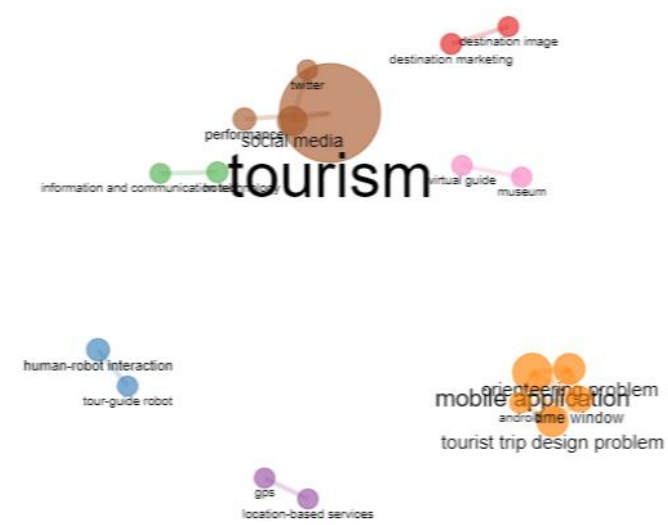

1- Yayınlara İlişkin Eşdizimlilik $A \breve{g}$ l

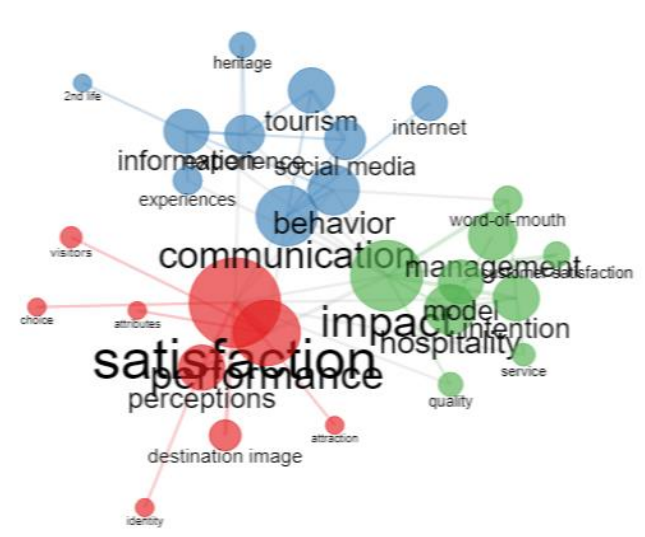

2- Atıf Yapılan Kaynaklara İlişkin Eşdizimlilik

Şekil 10'da yer alan birinci görsel incelendiğinde anahtar kelimelerin bir birine yakınlığına göre 7 farklı kümelenmenin olduğu görülmektedir. Bu kümelerden en büyüğünün turizm, sosyal medya ve performans kavramları etrafında olduğu görülürken, ikinci büyük kümenin mobil uygulamalar, yön bulma problemi, tur tasarım problemi ve zaman kavramları etrafinda yoğunlaştığı görülmektedir. Diğer kümelenmeler ise şu şekilde meydana gelmiştir: müze - arttırılmış gerçeklik; insan robot etkileşimi - tur rehberi robotları; lokasyon tabanlı hizmetler - GPS; destinasyon pazarlaması - destinasyon imajı ve otel - bilgi - iletişim teknolojileri.

Şekil 10 yer alan ikinci görsel incelendiğine birinci görsele göre daha az kümelenmenin oluştuğu göze çarpmaktadır. Bu noktada iletişim temalı turist rehberliği çalışmaları uzmanlık alanlarına göre ne kadar farklılaşsa da aynı alan yazına yöneldikleri ortaya çıkmaktadır. Bu bağlamda çalışmalar ne kadar farklılaşırsa farklılaşsın temel amacın iletişim ve iletişim teknoloji yoluyla turist rehberlerinin kabiliyetlerinin gelişmesine, destinasyon imajının oluşturulmasına, müşteri beklentilerinin karşılanması ve dolayısıyla müşteri memnuniyetinin sağlanmasına, teknolojik gelişmeler yoluyla müşterilerin daha az zamanda daha fazla deneyim kazanmasına katkı sağlamak olduğu söylenebilir.

İletişim temalı turist rehberliği çalışmalarından dünya çapında en fazla atıf almış yayınlar tablo 3'te gösterilmektedir. Çalışmamıza konu olan 318 yayımlanmış çalışmadan en çok atıf almış ilk 20 çalışma tablo 3'de gösterilmişsir. 
Turist Rehberliği Dergisi (TURED) \& Yıl. 2021, Cilt. 4, Sayı. 2

Journal of Tour Guiding (JOTOG) \& Year. 2021, Volume. 4, Issue. 2

Tablo 3

En Çok Atıf Alan Çalışmalar

\begin{tabular}{|c|c|c|}
\hline Yayınlar & $\begin{array}{l}\text { Toplam } \\
\text { Atıf }\end{array}$ & Atıf/Yll \\
\hline $\begin{array}{l}\text { Abowd, G. D., Atkeson, C. G., Hong, J., Long, S., Kooper, R., \& Pinkerton, M. (1997). } \\
\text { Usability Centre,“. Cyberguide: a mobile context-aware tour guide,” ACM Wireless } \\
\text { Networks, 3, 421-433. }\end{array}$ & 470 & 18,8 \\
\hline $\begin{array}{l}\text { Choi, S., Lehto, X. Y., \& Morrison, A. M. (2007). Destination image representation on the } \\
\text { web: Content analysis of Macau travel related websites. Tourism management, 28(1), 118- } \\
129 \text {. }\end{array}$ & 398 & 26,533 \\
\hline $\begin{array}{l}\text { Doerr, G., \& Dugelay, J. L. (2003). A guide tour of video watermarking. Signal processing: } \\
\text { Image communication, } 18(4), 263-282 \text {. }\end{array}$ & 208 & 10,947 \\
\hline $\begin{array}{l}\text { Ap, J., \& Wong, K. K. (2001). Case study on tour guiding: Professionalism, issues and } \\
\text { problems. Tourism management, 22(5), 551-563. }\end{array}$ & 192 & 9,1429 \\
\hline $\begin{array}{l}\text { Gavalas, D., Konstantopoulos, C., Mastakas, K., \& Pantziou, G. (2014). A survey on } \\
\text { algorithmic approaches for solving tourist trip design problems. Journal of } \\
\text { Heuristics, 20(3), 291-328. }\end{array}$ & 119 & 14,875 \\
\hline $\begin{array}{l}\text { Den Braber, F., Hogganvik, I., Lund, M. S., Stølen, K., \& Vraalsen, F. (2007). Model- } \\
\text { based security analysis in seven steps-a guided tour to the CORAS method. BT } \\
\text { Technology Journal, 25(1), 101-117. }\end{array}$ & 85 & 5,6667 \\
\hline $\begin{array}{l}\text { Randall, C., \& Rollins, R. B. (2009). Visitor perceptions of the role of tour guides in natural } \\
\text { areas. Journal of Sustainable Tourism, 17(3), 357-374. }\end{array}$ & 67 & 5,1538 \\
\hline $\begin{array}{l}\text { Jamal, T., \& Budke, C. (2020). Tourism in a world with pandemics: local-global } \\
\text { responsibility and action. Journal of Tourism Futures. }\end{array}$ & 67 & 33,5 \\
\hline $\begin{array}{l}\text { Malaka, R., \& Zipf, A. (2000). Deep Map: Challenging IT research in the framework of a } \\
\text { tourist information system. In Information and communication technologies in tourism } \\
2000 \text { (pp. 15-27). Springer, Vienna. }\end{array}$ & 56 & 2,5455 \\
\hline $\begin{array}{l}\text { Gretzel, U., Fuchs, M., Baggio, R., Hoepken, W., Law, R., Neidhardt, J., ... \& Xiang, Z. } \\
\text { (2020). e-Tourism beyond COVID-19: a call for transformative research. Information } \\
\text { Technology \& Tourism, 22, 187-203. }\end{array}$ & 56 & 28 \\
\hline $\begin{array}{l}\text { Gavalas, D., Kasapakis, V., Konstantopoulos, C., Pantziou, G., Vathis, N., \& Zaroliagis, } \\
\text { C. (2015). The eCOMPASS multimodal tourist tour planner. Expert systems with } \\
\text { Applications, } 42(21), 7303-7316 \text {. }\end{array}$ & 50 & 7,1429 \\
\hline $\begin{array}{l}\text { Liou, H. C. (2012). The roles of Second Life in a college computer-assisted language } \\
\text { learning (CALL) course in Taiwan, ROC. Computer Assisted Language Learning, 25(4), } \\
\text { 365-382. }\end{array}$ & & 4,6 \\
\hline $\begin{array}{l}\text { Jernsand, E. M., Kraff, H., \& Mossberg, L. (2015). Tourism experience innovation through } \\
\text { design. Scandinavian Journal of Hospitality and Tourism, 15(sup1), 98-119. }\end{array}$ & 39 & 5,5714 \\
\hline $\begin{array}{l}\text { Leclerc, D., \& Martin, J. N. (2004). Tour guide communication competence: French, } \\
\text { German and American tourists' perceptions. International Journal of Intercultural } \\
\text { Relations, 28(3-4), 181-200. }\end{array}$ & 37 & 2,0556 \\
\hline $\begin{array}{l}\text { Reijnders, S. (2010). Places of the imagination: An ethnography of the TV detective } \\
\text { tour. Cultural Geographies, } 17(1), 37-52 \text {. }\end{array}$ & 34 & 2,8333 \\
\hline $\begin{array}{l}\text { Weiler, B., \& Black, R. (2015). The changing face of the tour guide: one-way } \\
\text { communicator to choreographer to co-creator of the tourist experience. Tourism Recreation } \\
\text { Research, } 40(3), 364-378 \text {. }\end{array}$ & 33 & 4,7143 \\
\hline $\begin{array}{l}\text { Kahn Jr, P. H., Kanda, T., Ishiguro, H., Gill, B. T., Shen, S., Gary, H. E., \& Ruckert, J. H. } \\
\text { (2015, March). Will people keep the secret of a humanoid robot? Psychological intimacy } \\
\text { in HRI. In Proceedings of the Tenth Annual ACM/IEEE International Conference on } \\
\text { Human-Robot Interaction (pp. 173-180). }\end{array}$ & 31 & 4,4286 \\
\hline $\begin{array}{l}\text { Mayor, L., Jensen, B., Lorotte, A., \& Siegwart, R. (2002, September). Improving the } \\
\text { expressiveness of mobile robots. In Proceedings. 11th IEEE International Workshop on } \\
\text { Robot and Human Interactive Communication (pp. 325-330). IEEE. }\end{array}$ & 29 & 1,45 \\
\hline $\begin{array}{l}\text { Cai, S., Liao, W., Luo, C., Li, M., Huang, X., \& Li, P. (2016). CRIL: An efficient online } \\
\text { adaptive indoor localization system. IEEE Transactions on Vehicular Technology, 66(5), } \\
4148-4160 .\end{array}$ & 29 & 5,8 \\
\hline $\begin{array}{l}\text { Gavalas, D., Kasapakis, V., Konstantopoulos, C., Pantziou, G., \& Vathis, N. (2017). } \\
\text { Scenic route planning for tourists. Personal and Ubiquitous Computing, 21(1), 137-155. }\end{array}$ & 28 & 5,6 \\
\hline
\end{tabular}

Arıcı ve Pelit; İletişim temalı turist rehberliği çalışmalarının biblioshiny programı ile bibliyometrik analizi/ Bibliometric analysis of communication-themed studies in the field of tourist guiding with biblioshiny program 


\section{IIIII)}

Turist Rehberliği Dergisi (TURED) \& Yıl. 2021, Cilt. 4, Sayı. 2

Journal of Tour Guiding (JOTOG) \& Year. 2021, Volume. 4, Issue. 2

Tablo 3 incelendiğinde; dünya çapında en fazla atıf almış çalışmanın Abowd, G. D., Atkeson, C. G., Hong, J., Long, S., Kooper, R., ve Pinkerton, M. isimli yazarlar tarafindan 1997 yılında yayımlanan ve turistlerin mevcut konumları ile konumlarına ilişkin geçmiş elektronik kayıtlarından yola çıkarak bir rehberden beklenilen tur tasarım hizmetini verebilecek prototip bir uygulama projesi ortaya koydukları (Abowd, 1997) "Cyberguide: a mobile context-aware tour guide," isimli çalışma olduğu görülmektedir. Peşi sıra gelen ve 100 'ün üzerinde atıf almış çalışmalar değerlendirildiğinde beş çalışmadan dördünün teknoloji tabanlı turist rehberliği çalışmaları olduğu görülmektedir.

Dünya çapında en çok atıf almış yayınlarla şekil 6' da listelenmiş olan en ilgili yazarlar sıralamasının farklı olduğu göze çarpmaktadır. Kısacası en ilgili yazarlar sırlamasında en üste olan yazarların en çok atıf alan yazarlar olmadığı görülmüştür. Bu noktada yapılan incelemede en ilgili yazarlar sıralamasında (en çok yayın yapan) ilk 10'a girmiş yazarların bir birleriyle ortak birden fazla yayınlarının olması söz konusu durumu açıklar niteliktedir.

Şekil 11'de iletişim temalı turist rehberliği çalışmalarının isimlerine ve yazar isimlerine göre doğrudan alıntı ağları ortaya konmuştur. İki görselden oluşan Şekil 11 'in birinci görselinde çalışma isimlerine göre tarihsel doğruda alıntı ağı gösterilirken, ikincisinde aynı alıntı ağı yazar isimlerine göre görselleştirilmiştir. Ayrıca görseldeki yoğunluğu engellemek adına son 20 yıl değerlendirme kapsamına alınmıştır.

\section{Sekil 11}

Çalışma ve Yazar İsimlerine Göre Tarihsel Doğrudan Alıntı Ă̆ları
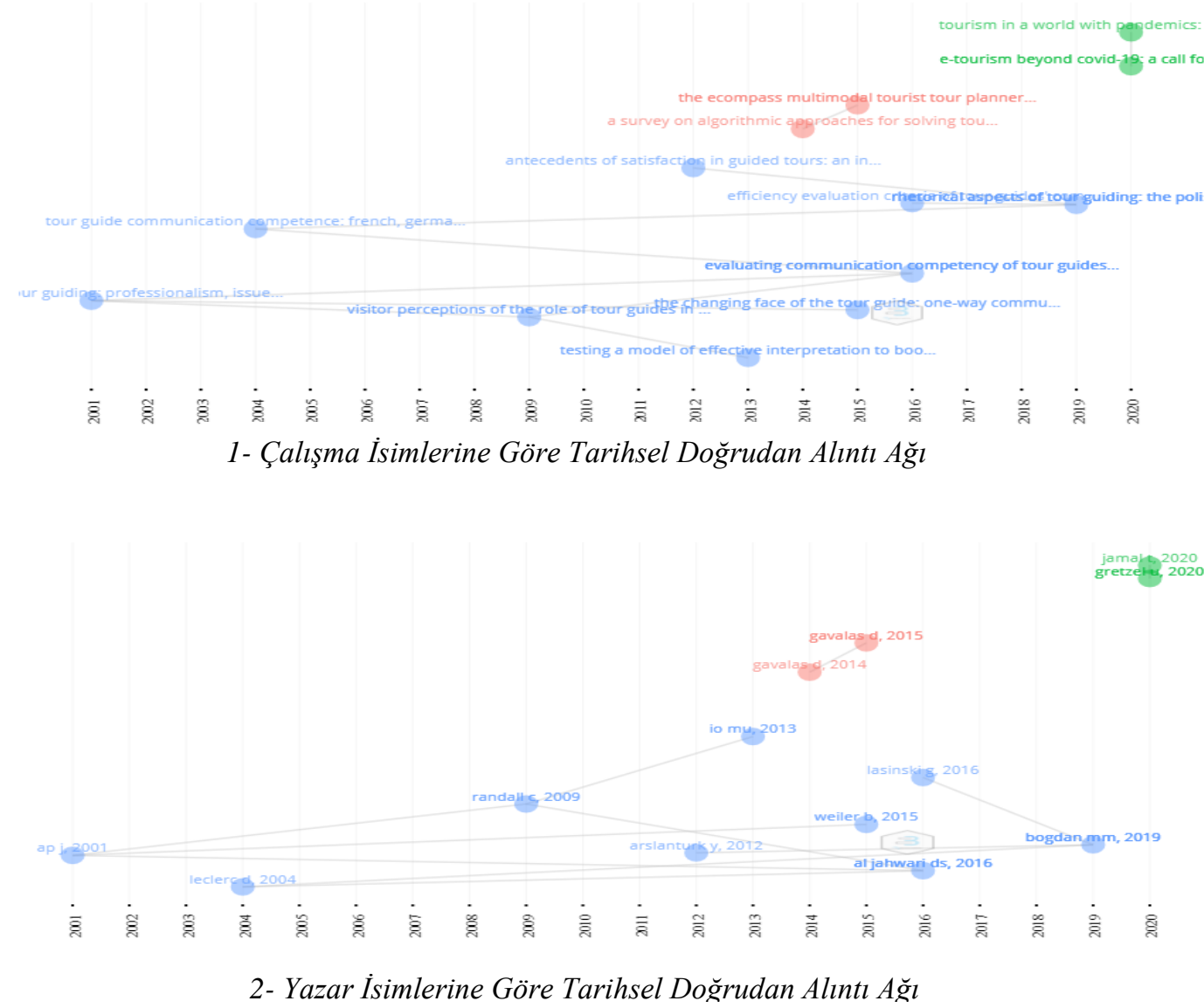

Arıcı ve Pelit; İletişim temalı turist rehberliği çalıșmalarının biblioshiny programı ile bibliyometrik analizi/ Bibliometric analysis of communication-themed studies in the field of tourist guiding with biblioshiny program 


\section{IIIII)}

Turist Rehberliği Dergisi (TURED) \& Yıl. 2021, Cilt. 4, Sayı. 2

Journal of Tour Guiding (JOTOG) \& Year. 2021, Volume. 4, Issue. 2

Şekil 11'de yer alan iki görsel birlikte değerlendirildiğinde; öncelikle üç farklı kümelenmenin olduğu göze çarpmaktadır. Bu kümelerin içeriği incelendiğinde "mavi” renkle gösterilen kümenin rehberlik mesleğinin özellikleri, mesleğin görev ve sorumlulukları, turist rehberlerinin sahip olması gereken iletişim becerileri ve iletişim yeterlilikleri, mesleğin icrası ile müşteri memnuniyeti arasındaki ilişki, müşterilerin turist rehberlerinden beklentileri ve turist rehberliği ile destinasyon pazarlaması arasındaki ilişki gibi bir biriyle ilintili çalışmalardan oluştuğu görülmektedir. Son 20 yıllık mavi renkli doğrudan alıntı ağında yer alan ilk yayının Ap. J ve Wong K.K. isimli yazarlara ait 2001 yılında yayınlanan ve profesyonel turist rehberlerinin hizmet standartlarını değerlendiren, mesleğin 21yy.'da karşılaştığ problemleri ortaya koyan (Ap ve Wong, 2001) "Case study on tour guiding: Professionalism, issues and problems" isimli yayın olduğu görülmektedir. Bunun yanı sıra diğer öncü yayının ise Leclerc, D. ve Martin, J.N. tarafından 2004 yılında yayınlanan ve turist rehberlerinin iletişim yetkinliklerini Fransız, Alman ve Amerikalı turistler gözünden değerlendiren (Leclerc ve Martin, 2004) "Tour guide communication competence: French, German and American tourists' perceptions" isimli çalışmanın olduğu göze çarpmaktadır. Söz konusu iki çalışma bu kümede yer alan diğer yayınların son 20 yıldaki öncüleri niteliğindedir.

Kırmızı renkle gösterilen diğer kümenin ise özellikle mobil turist rehberliği uygulamalarına, teknoloji tabanlı uygulamaların verimliliğini artırmaya ve bu doğrultuda turistlerin tur planlama problemlerinin çözümüne yönelik öneriler geliştiren çalışmalar olduğu görülmektedir. Bu kümenin öncüsü niteliğindeki çalışmanın ise Gavalas, D., Konstantopoulos, C., Mastakas, K. Ve Pantziou, G. isimli yazarlara ait 2014 yılında yayınlanan, turistlerin tur tasarımında karşılaştıkları problemlerin çözümüne yönelik turist tercihleriyle eşleşen ve bu sayede turist memnuniyetini en üst seviyeye taşımayı amaçlayan algoritmik yaklaşım ortaya koydukları (Gavalas, vd., 2014) "A survey on algorithmic approaches for solving tourist trip design problems" isimli çalışmaları olduğu ortaya çıkmaktadır.

Son olarak yeşil renkle karşımıza çıkan doğrudan alıntı ağı kümesi ise dünyanın en güncel ve büyük sorunu olan COVİD - 19 sürecinde dünyada turizmin tartış1ldı̆̆ , yerel ve global sorumlulukların ve Covid - 19 sonrası turizmi bekleyen değişkenlerin tartışıldığı küme olarak karşımıza çıkmaktadır. Tarihsel doğrudan alıntı ağı incelendiğinde son 10 yılın trend topik araştırma anahtar kelimelerinin ortaya konduğu Şekil 8 ile araştırma içerikleri anlamında paralellik göze çarpmaktadır.

\section{Sonuç ve Öneriler}

İletişim temalı turist rehberliği çalışmalarının yıllar içerisinde nasıl bir gelişim gösterdiğini tespit etmek ve turist rehberliği alan yazınında iletişim temalı çalışmaların genel özelliklerini ortaya koymak için yapılan bu çalışmada; Clarivate şirketi tarafindan yönetilen web of science (WoS) veri tabanından erişilen ve 1988 - 2021 yılları arasında yayımlanmış toplam 318 çalışma değerlendirilmiştir.

Elde edilen sonuçlara göre değerlendirme kapsamına alınan yayınların çoğunluğunu makaleler oluştururken azımsanmayacak sayıda bildirinin olduğu, söz konusu çalışmaların çoğunlukla birden fazla yazar tarafından kaleme alındığı tespit edilmiştir. İlgili yayınların yıllara göre dağılımı incelendiğinde ise son on yılda yayımlanan yayın sayısında büyük bir artış gözlenmiştir. Değerlendirmeye alınan çalışmalar, araştırmacıların bilimsel üretkenliği açısından değerlendirildiğinde; araştırmacıların neredeyse tamamına yakınının iletişim temalı turist rehberliği alan yazınına sadece bir yayınla katkı gösterdiği tespit edilmiştir. İletişim temalı turist rehberliği çalışmaları Lotka yasasına göre değerlendirildiğinde ilgili alan yazının yetersiz ve geliştirilmesi gerektiği sonucuna varılmıştır. 


\section{IIIII)}

Turist Rehberliği Dergisi (TURED) \& Yıl. 2021, Cilt. 4, Sayı. 2

Journal of Tour Guiding (JOTOG) \& Year. 2021, Volume. 4, Issue. 2

İletişim temalı turist rehberliği alanında yayımlanan çalışmalar yazarlarının ülkeleri açısından değerlendirildiğinde en fazla yayının ABD ve Çin kaynaklı olduğu görülmektedir. Aynı zamanda çalışmalarda büyük bir çoğunluğun tek ülkeli yazarlı olduğu göze çarpmaktadır.

İletişim temalı turist rehberliği ile ilgili en fazla makale yayını yapılan dergi " 8 " yayınla Tourism Culture and Communication Dergisi olurken, dergi başına 5'er yayınla Current Issues in Tourism, International Journal of Tourism Cities, Journal of Hospitality and Tourism Technology, Journal of Sustainable Tourism ve Scandinavian Journal of Hospitality and Tourism dergileridir. Ayrıca ilk 20 dergi arasına giren diğer dergiler ise $2-4$ arasında yayın yapmıştır. İlk 20 giren dergilerin $2-8$ arasında makale yayınlamış olması, turizm rehberliği alanında iletişim konusu ile ilgili yayın yapan araştırmacı sayısının yetersiz olduğunu bir kez daha ortaya koymaktadır. Genel olarak turizm rehberliği alan yazının henüz gelişme aşamasında olması (Kaygalak-Çelebi \& Kırlar-Can, 2019; Şahin \& Acun, 2015), iletişim temalı yayınların da yetersiz olmasına gerekçe olarak gösterilebilir.

Kaynaklara göre en çok atıf alan çalışmaların yayımlandığı kaynaklar incelendiğinde, 330 atıfla en çok atıf alan derginin "Tourism Management" isimli dergi olduğu, bu dergiyi 281 atıfla yakından takip eden diğer derginin ise "Annals of Tourism Research" isimli dergi olduğu göze çarpmaktadır. $\mathrm{Bu}$ noktada iletişim temalı turist rehberliği çalışmalarının en çok yayımlandığı dergiler ile kaynak yayınların bulunduğu dergilerin sıralama açısından farklılaştı̆g 1 görülmektedir. Çalışmamızda iletişim alanıyla ilgili turist rehberliği çalışmaları incelenmesinden kaynaklı, farklı uzmanlık alanına sahip araştırmacıların yayınları araştırma kapsamına girmiştir. Bu sebepledir ki araştırmacılar kendi uzmanlık alanlarına göre yayım yapan dergileri tercih etmekte, ancak alan yazın taraması esnasında özellikle turizm alanında yayım yapan dergilere doğal olarak yönelmektedir.

Son on yıl içerisinde iletişim tabanlı rehberlik çalışmalarında hangi konuların hangi yıllarda trend olduğu incelendiğinde 2010'lu yılların ortalarında mobil uygulamalar tabanlı turist rehberliği çalışmalarının yapıldığı görülürken ilerleyen yıllarda turist rehberlerinin iletişim yetkinliklerinin ve iletişim teknolojilerindeki gelişmelerin destinasyon imaj1 oluşturma ve destinasyon pazarlamasına katkıları noktasında çalışmaların yaygınlaştığı görülmektedir. Son yıllarda yapılan ilgili çalışmalara bakıldığında ise iletişimden sosyal medya iletişimine, gerçeklikten sanal gerçekliğe doğru bir evrilmenin söz konusu olduğu görülmektedir. Bu bağlamda iletişim temalı turist rehberliği çalışmalarının yıllar içerisinde teknolojinin gelişmesine ve bu gelişmenin sunduğu avantajlara dayalı olarak dönüşüm geçirdiği söylenebilir.

WoS veri tabanından elde edilen iletişim temalı turist rehberliği çalışmalarında kullanılan anahtar kelimelerin ve bu çalışmaların alan yazın taramasında kullanılan kaynak yayınlarında kullanılan anahtar kelimelerin kullanım sıklıklarını incelenmiş ve iletişim temalı turist rehberliği çalışmalarının hangi konular üzerinde yoğunlaştığı irdelenmeye çalışılmıştır. Buna göre; çalışmalarda en sık kullanılan anahtar kelimelerin turist, turist rehberi, iletişim, mobil uygulamalar, sanal gerçeklik, destinasyon pazarlaması, destinasyon imajı, insan-robot etkileşimi vb. gibi kelimeler olduğu ortaya çıkarken; atıf yapılan kaynak yayınlarda sıklıkla kullanılan anahtar kelimelerin memnuniyet, performans, iletişim, yönetim, davranış, algı, internet vb. kelimeler olduğu görülmektedir. Bu bağlamda atıf yapılan kaynaklara ilişkin anahtar kelimelerde bahsi geçen kelimelerin çoğunlukla kullanılması; iletişim temalı turist rehberliği çalışmalarında iletişimin müşteri memnuniyeti üzerindeki etkisinin ve turist rehberlerinin ve tur programlarının performansları üzerinki öneminin yaygın olarak araştırıldığını ortaya koymaktadır. 
Turist rehberlerinin gelişmiş iletişim becerilerine sahip olması gerekliliği alan yazında sıkça vurgulanmaktadır. Buna karşın çalışmanın evrenini oluşturan yayınların anahtar kelimeleri ve atıf yapılan kaynak yayınlarda kullanılan anahtar kelimeler incelendiğinde, en s1k kullanılan 20 kelime içerisinde "eğitim" kavramına rastlanamamıştır. Sadece en s1k kullanılan 50 kelimenin dahil edildiği kelime bulutlarında "eğitim" ve "öğrenme" kavramlarının küçük puntolar şeklinde karşımıza çıktığ 1 görülmektedir. Bu durum turist rehberlerinin iletişim becerilerinin geliştirilmesine katkı sağlayacak çalışmalara yeterince yer verilmediğini göstermektedir. Bu noktada, iletişim becerisinin doğuştan gelen bir yetenek olmadığ1, eğitim düzeyi arttıkça bu becerilerin gelişebileceği (Hodges et al., 1996) ve iletişim tekniklerinin öğretilebilir olduğu (Egan, 1994; Buckman, 2001; Corey, 2001) düşüncelerinden hareketle ilgili alana yönelimin artması gerektiği düşünülmektedir.

Turizm rehberliği alan yazınında iletişim konusuyla ilgili çalışmaların ve bu alanda uzmanlaşmış akademisyen sayısının yetersizliği oldukça dikkat çekicidir. Bu durum turizm ve turist rehberliği araştırmacıları için firsatları da beraberinde getirmektedir. Bu noktada araştırmacılara bazı öneriler geliştirilmiştir. Bunlar;

- Turist rehberliği çalışan araştırmacıların iletişim temalı çalışmalara yönelmesi ve konuyla en ilgili araştırmacılar listesine Türk araştırmacıların katılması sağlanmalı.

- Çok ülkeli yayınların yetersizliği sebebiyle farklı ülkelerde ilintili alanlarda hizmet veren akademisyenlerle iş birliği yapılarak çok ülkeli yayınların sayıları arttırılmalı.

- Araştırmanın bulgularında görüldüğü üzere güncel çalışmaların, hızla gelişen iletişim teknolojileri ile ilişkili olması sebebiyle, turizm akademisyenleri iletişim teknolojileri alanında çalışan akademisyenlerle birlikte, teknolojinin turist rehberlerinin kabiliyetlerini geliştirmesine katkı sağlayacak, disiplinler arası çalışmalara yönelmeli.

- Eğitimin öneminin üzerinde durularak, turist rehberlerinin iletişim becerilerini geliştirmesine katkı sağlayacak disiplinler arası akademik çalışmalar arttırılmalı.

- İletişim temalı turist rehberliği çalışmalarını yürüten araştırmacıların çalışmalarını uluslararası mecralarda yayımlatması hususunda teşvik edilmelidir.

\section{Kaynakça}

Abowd, G. D., Atkeson, C. G., Hong, J., Long, S., Kooper, R., \& Pinkerton, M. (1997). Usability Centre, Cyberguide: a mobile context-aware tour guide. ACM Wireless Networks, 3, 421-433.

Ap, J., \& Wong,, K. K. (2001). Case study on tour guiding: Professionalism, issues and problems. Tourism Management, 22(5), 551-563.

Arat, T. \& Bulut, H.Ç. (2019). Turist memnuniyetinde turist rehberinin rolü: Konya'da bir araştırma. Turist Rehberliği Dergisi, 2(1), 31-43.

Arden E. \& Boggs U. K. (1999). Interpersonal Relationships. W. B. Saunders Company.

Batman, O., Yıldırgan, R. \& Demirtaş, N. (2001). Turizm Rehberliği. Değişim Yayınları.

Bilen, M. (1995). Sağlıklı İnsan İlişkileri, Armoni Yayınları.

Boyraz, M., Kabakulak, A., \& Mutlu, A. S. (2020). Hazırlanmakta olan turizm konulu lisansüstü tezlerin veri görselleştirme tekniği ile bibliyometrik analizi: 2006-2020 y1lları örneği. Türk Turizm Araştırmaları Dergisi, 4(2), 1434-1453.

Boyraz, M., \& Kabakulak, A. (2020). Türkiye'deki turizm rehberliği bölümlerinde görev yapan akademisyenlerin bilimsel yayınlarının bibliyometrik analizi. Türk Turizm Araştırmaları Dergisi, 4(3), 2152-2163. 
Buckman, R. ( 2001) Communication skills in palliative care. Neurologic Clinics, 19(4), 9891004.

Burleson, B. R., \& Holmstrom, A. J. (2008). Comforting communication. The international encyclopedia of communication. John Wiley \& Sons, Ltd.

Büyükkuru, M., \& Aslan, Z. (2016). Turist rehberlerinin iletişim becerilerinin turistlerin tur deneyimi üzerine etkisi: Nevşehir ilinde bir araştırma. Mustafa Kemal Üniversitesi Sosyal Bilimler Enstitüsü Dergisi, 13(34), 338-354.

Caber, M., Yilmaz, G., Kilicarslan, D. \& Öztürk, A. (2018). The effects of tour guide performance and food involvement on food neophobia and local food consumption intention. International Journal of Contemporary Hospitality Management, 30(3), 14721491.

Cai, S., Liao, W., Luo, C., Li, M., Huang, X., \& Li, P. (2016). CRIL: An efficient online adaptive indoor localization system. IEEE Transactions on Vehicular Technology, 66(5), 4148-4160.

Chang, K. (2014). Examining the effect of tour guide performance, tourist trust, tourist satisfaction, and flow experience on tourists' shopping behavior. Asia Pacific Journal of Tourism Research, 19(2), 219-247.

Cheng, Y., Kuo, N., Chang, K. \& Chen, C. (2019). How a tour guide interpretation service creates intention to revisit for tourists from mainland China: The mediating effect of perceived value. Journal of China Tourism Research, 15(1), 84-104.

Cheverst, K., Mitchell, K. \& Davies, N. (2002). The role of adaptive hypermedia in a contextaware tourist guide. Communication of ACM. 45(5), 47-51.

Choi, S., Lehto, X. Y., \& Morrison, A. M. (2007). Destination image representation on the web: Content analysis of Macau travel related websites. Tourism Management, 28(1), 118129.

Claypool, C. (2003). Improving the communication skills of your most valuable resource: Your people. Techniques Association for Career \& Technical Education, 78(1), 56-57.

Corey, G. (2001). Theory and practice of counseling and psychotherapy (6. Bask1). Brooks/Cole.

Cüceloğlu D (2002). İletişim donanımları. Remzi Kitabevi.

Çağlar, İ. \& Kılıç, S. (2008). Eğitim fakülteleri için genel iletişim. Nobel Yayın Dağıtım.

Çetinkaya, M. Y. V. \& Öter, Z. (2016). Role of tour guides on tourist satisfaction level in guided tours and impact on re-visiting Intention: a research in Istanbul. European Journal of Tourism, Hospitality and Recreation, 7(1), 40-54.

Den Braber, F., Hogganvik, I., Lund, M. S., Stølen, K. \& Vraalsen, F. (2007). Model-based security analysis in seven steps - a guided tour to the CORAS method. BT Technology Journal, 25(1), 101-117.

Doerr, G., \& Dugelay, J. L. (2003). A guide tour of video watermarking. Signal processing: Image communication, 18(4), 263-282.

Dökmen Ü (2003). Yarına kim kalacak? Evrenle uyumlaşma sürecinde varolmak gelişmek uzlaşmak. Sistem Yayıncılık.

Dönbak, E. R. (2021). Tur rehberi performansı ve turist memnuniyeti arasındaki ilişkinin meta analizi: Uluslararası literatür örneği. Sosyal, Beşeri ve İdari Bilimler Dergisi, 4(1), 1-16.

Duman, G. \& Mil, Z. (2008). Akademik görüş: Turist rehberliği ve eğitimi. Seyahat ve Otel İsletmeciliği Dergisi, 5(4), 1-6.

Egan, G. (1994). Psikolojik danışmaya giriş. (Akkoyun F. Çev). Form Ofset.

Eser, E. \& Çakıc1, A. C. (2021). Does physical apperance of tourist guides affect tourist' satisfaction? Turizm Akademik Dergisi, 8(1), 297-308. 
Garcia, A., Linaza, M., Arbelaitz, O. \& Vansteenwegen, P. (2009): Intelligent routing system for a personalised electronic tourist guide. In Hpken, W., Gretzel, U. \& Law, R., (eds) Information and Communication Technologies in Tourism (185-197). Springer; Wien New York.

Gavalas, D., Konstantopoulos, C., Mastakas, K., \& Pantziou, G. (2014). A survey on algorithmic approaches for solving tourist trip design problems. Journal of Heuristics, 20(3), 291-328.

Gavalas, D., Kasapakis, V., Konstantopoulos, C., Pantziou, G., Vathis, N., \& Zaroliagis, C. (2015). The eCOMPASS multimodal tourist tour planner. Expert Systems with Applications, 42(21), 7303-7316.

Gavalas, D., Kasapakis, V., Konstantopoulos, C., Pantziou, G., \& Vathis, N. (2017). Scenic route planning for tourists. Personal and Ubiquitous Computing, 21(1), 137-155.

George, B. (2011). Communication skills for success: Tourism industry specific guidelines. The Magazine of Global English Speaking Higher Education, 3(1), 13-14.

Giffin, K. \& Patton, B. R. (1997). Basic Readings in Interpersonal Communication, New York: Harper-Row.

Gretzel, U., Fuchs, M., Baggio, R., Hoepken, W., Law, R., Neidhardt, J., \& Xiang, Z. (2020). e-Tourism beyond COVID-19: A call for transformative research. Information Technology \& Tourism, 22, 187-203.

Güzel, F., \& Köroğlu, Ö. (2014). Turist rehberlerinin liderlik ve aracilık rollerinin tur deneyimine etkisi: Doğa turları üzerine bir araştırma. Gaziantep University Journal of Social Sciences, 13(4) 939-960.

Hodges, B., Turnbull, J., \& Cohen, R. (1996). Evaluating communication skills in the objective structured clinical examination format: Reliability and generalizability. Medical Education, 30(1), 38-43.

Işı1k, M. (2012). Kitle iletişim teorilerine giriş. Eğitim Yayınevi.

İpar, M. S., \& Doğan, M. (2103). Destinasyonun turist açısından önem-memnuniyet model ile değerlendirilmesi: Edremit üzerine bir uygulama. Adlyaman Üniversitesi Sosyal Bilimler Enstitüsü Dergisi, 13(6), 129-154.

Jamal, T., \& Budke, C. (2020). Tourism in a world with pandemics: local-global responsibility and action. Journal of Tourism Futures. 6(2), 181-188.

Jernsand, E. M., Kraff, H., \& Mossberg, L. (2015). Tourism experience innovation through design. Scandinavian Journal of Hospitality and Tourism, 15(1), 98-119.

Johnson, D. W. \& Johnson, F. P. (1997). Joining together group theory and group skills (6. Bask1). Allyn and Bacon.

Kahn Jr, P. H., Kanda, T., Ishiguro, H., Gill, B. T., Shen, S., Gary, H. E., \& Ruckert, J. H. (2015, March). Will people keep the secret of a humanoid robot? Psychological intimacy in HRI. In Proceedings of the Tenth Annual ACM/IEEE International Conference on Human-Robot Interaction (ss. 173-180).

Kaya, A. R. (1985). Kitle iletişim sistemleri: Basın, radyo ve televizyon yayınlarının düzenlenmesi. Teori Yayınları.

Kaygalak-Çelebi, S., \& Kırlar-Can, B. (2019). Turizm rehberliği alanında yapılan makalelerin bibliyometrik analizi. International Journal of Contemporary Tourism Research, 3(2), 213-223.

Keenan, Kate. (1997). Yöneticinin Kılavuzu-İletişim Kurma (V. Atayman Çev.). Remzi Kitabevi.

Kumar, N. M., \& Gilula, N. B. (1996). The gap junction communication channel. Cell, 84(3), 381-388. 
Leclerc, D., \& Martin, J. N. (2004). Tour guide communication competence: French, German and American tourists' perceptions. International Journal of Intercultural Relations, 28(34), 181-200.

Li, Y., Hu, C., Huang, C. \& Duan, L. (2017). The concept of smart tourism in the context of tourism information services. Tourism Management, 58(C), 293-300.

Liou, H. C. (2012). The roles of Second Life in a college computer-assisted language learning (CALL) course in Taiwan, ROC. Computer Assisted Language Learning, 25(4), 365-382.

Lotka, A.J. (1926). The frequency distribution of scientific productivity. Journal of the Washington Academy of Sciences, 16(12), 317-323.

Malaka, R., \& Zipf, A. (2000). Deep Map: Challenging IT research in the framework of a tourist information system. In Information and communication technologies in tourism 2000 (ss. 15-27). Springer, Vienna.

Massimo, A., \& Corrado, C. (2021, Eylül 8) Biblioshiny bibliometrix for no coders. https://www.bibliometrix.org/biblioshiny/

Mayor, L., Jensen, B., Lorotte, A., \& Siegwart, R. (2002, Eylül). Improving the expressiveness of mobile robots. In Proceedings. 11th IEEE International Workshop on Robot and Human Interactive Communication (ss. 325-330). IEEE.

Oğuzkan F. (2003). Illetişim. İçinde Eğitim Terimleri Sözlüğü. Emel Matbaacılık.

Örnek, N., \& Karamustafa, K. (2020). Turist Rehberliği Alanındaki Lisansüstü Tezlerin Bibliyometrik Analiz ile Değerlendirilmesi (1989-2019). Turist Rehberliği Dergisi (TURED), 3(2), 115-138.

Özer, K.(2000). Illetişimsizlik Becerisi, Sistem Yayınc1lık.

Özsoy, A., \& Çokal, Z. (2018). Türkiye'de turist rehberliği alanında yayımlanmış lisansüstü tezlerin bibliyometrik analizi (1989-2018). 2. International EMI Entrepreneurship \& Social Sciences Congress, 09-11 November 2018, Cappadocia, 1404-1414.

Pelit, E., \& Karaçor, M. (2015). A study on tourism students' communication skills: Afyon Kocatepe University example. Gaziantep University Journal of Social Sciences, 14(4), 847-872.

Peracchio, L. A., \& Luna, D. (2006). The Role of ThinSlice Judgments in Consumer Psychology. Journal of Consumer Psychology, 16(1), 25-32.

Pritchard, A. (1969). Statistical bibliography or bibliometrics. Journal of Documentation, 25(4), 348-349.

Randall, C., \& Rollins, R. B. (2009). Visitor perceptions of the role of tour guides in natural areas. Journal of Sustainable Tourism, 17(3), 357-374.

Reijnders, S. (2010). Places of the imagination: An ethnography of the TV detective tour. Cultural Geographies, 17(1), 37-52.

Ruhanen, L., Weiler, B., Moyle, B. \& McLennan, C. (2015). Trends and patterns in sustainable tourism research: A 25 year bibliometric analysis. Journal of Sustainable Tourism, 23(4), 517-535.

Saltık, İ. A. (2020). Turist rehberliği konulu ulusal lisansüstü tezlerin bibliyometrik profili (1989-2018). Çankırı Karatekin Üniversitesi Sosyal Bilimler Enstitüsü Dergisi, 11(1), 4569.

Sandaruwani, J. R. C., \& Gnanapala, W. A. C. (2016). The role of tourist guides and their impacts on sustainable tourism development: A critique on Sri Lanka. Tourism, Leisure and Global Change, 3, 62-73.

Şahin, S., \& Acun, A. (2015). Turist rehberliği alanının bibliyometrik profili (Ulusal turizm kongreleri bildirileri). Balıkesir Üniversitesi Sosyal Bilimler Enstitüsü Dergisi, 18(34), 213-234. 
Şahin, S. Ş. \& Avcıkurt, C. (2013). Turist rehberlerinin iletişim yeterlilikleri: Turistlerin görüşlerinin chaid analizi ile değerlendirilmesi. Balıkesir Üniversitesi Sosyal Bilimler Enstitüsü Dergisi, 16(29), 303-327.

Tseng, M. L., Chang, C. H., Lin, C. W. R., Wu, K. J., Chen, Q., Xia, L., \& Xue, B. (2020). Future trends and guidance for the triple bottom line and sustainability: A data driven bibliometric analysis. Environmental Science and Pollution Research, 27, 33543-33567.

Tosun, C., \& Temizkan, R. (2004, Nisan 15-16). Türkiye'nin Dış Tanıtım ve Ülke İmajında Turist Rehberlerinin Rolü. 1. Balıkesir Ulusal Turizm Kongresi Bildirileri, Balıkesir, Türkiye.

Tsaur, S. H., Dai, Y.Y. \& Liu, J.S. (2018). SOCO's impact on service outcomes of tour guides: the moderating effect of customers' shopping orientation. Current Issues in Tourism, 21(8), 917-933.

Tutar, H. \& Yılmaz, M. K. (2003). Genel iletişim. Nobel Yayınları.

Ünüvar, Ş. (2008). Turizm sektöründe bilgi iletişim teknolojileri kullanımı. Selçuk Üniversitesi Sosyal Bilimler Meslek Yüksekokulu Dergisi, 10(1-2), 597-618.

Üstün, B. (2005). Çünkü iletişim çok şeyi değiştirir! Anadolu Hemşirelik ve Sağllk Bilimleri Dergisi, 8(2), 88-94.

Vansteenwegen, P., \& Van Oudheusden, D. (2007): The mobile tourist guide: an or opportunity. Oper. Res. Insight 20(3), 21-27.

Verdener, R. F. (1999). Communicate! (9. Bask1). Wadsworth Publishing Company.

Weiler, B., \& Black, R. (2015). The changing face of the tour guide: one-way communicator to choreographer to co-creator of the tourist experience. Tourism Recreation Research, 40(3), 364-378.

Yalcinkaya, P., Atay, L. \& Karakaş, E. (2018). Akıllı turizm uygulamaları. Gastroia: Journal of Gastronomy And Travel Research, 2(2), 34-52. doi:10.32958/gastoria.433831.

Yen, C., Chen, C., Cheng, J. \& Teng, H. (2018). Brand attachment, tour leader attachment, and behavioral intentions of tourists, Journal of Hospitality \& Tourism Research, 42(3): 365-391.

Yetgin, D. (2017). Turist rehberlerinin tükenmişlik ve ekonomik kaygı düzeylerinin mesleki bağlllık düzeyleri üzerindeki etkisi. (Tez No. 458680). (Doktora Tezi, Anadolu Üniversitesi). YÖK Tez https://tez.yok.gov.tr/UlusalTezMerkezi/tezSorguSonucYeni.jsp.

Yıldırım, C. (2009). Kültür turizmi kapsamındaki iletişim çalışmaları: 2010 istanbul avrupa kültür başkenti üzerine bir araştırma. (Tez No. 241219). (Doktora Tezi, Marmara Üniversitesi). YÖK Tez Merkezi. https://tez.yok.gov.tr/UlusalTezMerkezi/tezSorguSonucYeni.jsp.

Yüksel, Ö. (2006). Davranış Bilimleri. Gazi Kitabevi.

$\mathrm{Yu}, \mathrm{Xin}$, Weiler, Betty \& Ham, Sam. (2002). Intercultural communication and mediation: A framework for analysing the intercultural competence of Chinese tour guides. Journal of Vacation Marketing, 8(1), 75-87.

Zengin, B., \& Atasoy, B. (2020). Turizm rehberliği alanındaki lisansüstü tezlerin bibliyometrik çerçevesi. Alanya Akademik Bakış, 5(1), 143-160. 
Turist Rehberliği Dergisi (TURED) \& Yıl. 2021, Cilt. 4, Sayı. 2

Journal of Tour Guiding (JOTOG) \& Year. 2021, Volume. 4, Issue. 2

\section{ETIK ve BILIMSEL ILKELER SORUMLULUK BEYANI}

Bu çalışmanın tüm hazırlanma süreçlerinde (veri toplama, yazım vb.), tüm etik kurallara ve bilimsel atıf gösterme ilkelerine riayet edildiğini, herhangi bir hataya mahal vermemek için yayımdan önce makalenin bir intihal programı aracılığıyla da kontrol edildiğini yazarlar beyan eder. Ayrıca yazarlar aşağıda sıralanan hususları kabul etmiştir:

1. Calıșmada yer alan ve kullanılan tüm kaynaklara, bilimsel araștırma yöntemleri ve etik ilkeler doğrultusunda atıf yapılmıştır

2. Çalışmada tüm yazarların akademik-bilimsel olarak doğrudan ve ortak katkısı vardır.

3. Bu çalışma, yazarların özgün bir çalışmasıdır.

4. Bütün yazarlar dergiye gönderilen makaleyi görmüș ve sonuçlarını onaylamıștır.

5. Çalışmada kullanılan denek/deneklere ilişkin herhangi bir etik ihlal yapılmamış, kullanılan tüm veri toplama yöntemlerinde bilimsel etik ilkelere göre hareket edilmiștir.

6. Çalışma daha önceden bilimsel bir toplantıda sunulan özet veya bu çalışmanın daha kısa hali ise, makalede bu durum belirtilmiștir.

7. Çalışmada, hiçbir suç unsuru veya kanuna aykırı ifade bulunmamakla birlikte, araştırma yapılırken kanuna aykırı herhangi bir yöntem kullanılmamış olup, çalışma ile ilgili tüm yasal izinler alınmış ve etik kurallara uygun hareket edilmiştir.

Aksi bir durumun tespiti halinde Turist Rehberliği Dergisi'nin hiçbir sorumluluğu olmayıp, tüm sorumluluk makale yazarlarına aittir.

Tarih : $01 / 11 / 2021$

Sorumlu Yazar : : Semih ARICI

Arıcı ve Pelit; İletişim temalı turist rehberliği çalışmalarının biblioshiny programı ile bibliyometrik analizi/ Bibliometric analysis of communication-themed studies in the field of tourist guiding with biblioshiny program 